OPEN ACCESS

Edited by:

Luca Antonioli,

University of Pisa, Italy

Reviewed by:

Rocchina Colucci,

University of Padova, Italy

Maria Cecilia Giron,

University of Padova, Italy

*Correspondence:

Simona Bertoni

simona.bertoni@unipr.it

tThese authors have contributed equally to this work.

Specialty section: This article was submitted to

Gastrointestinal and

Hepatic Pharmacology,

a section of the journal

Frontiers in Pharmacology

Received: 13 March 2019

Accepted: 27 May 2019

Published: 17 June 2019

Citation:

Grandi A, Zini I, Palese S, Giorgio C, Tognolini M, Marchesani F, Bruno S, Flammini L, Cantoni AM, Castelli R, Lodola A, Fusari A, Barocelli E and Bertoni S (2019) Targeting the Eph/Ephrin System as Anti-Inflammatory Strategy in IBD.

Front. Pharmacol. 10:691.

doi: 10.3389/fphar.2019.00691

\section{Targeting the Eph/Ephrin System as Anti-Inflammatory Strategy in IBD}

\author{
Andrea Grandi ${ }^{1 \dagger}$, Irene Zini ${ }^{1+}$, Simone Palese ${ }^{1}$, Carmine Giorgio ${ }^{1}$, Massimiliano Tognolini ${ }^{1}$, \\ Francesco Marchesani ${ }^{1}$, Stefano Bruno ${ }^{1}$, Lisa Flammini ${ }^{1}$, Anna Maria Cantoni ${ }^{2}$, \\ Riccardo Castelli ${ }^{1}$, Alessio Lodola ${ }^{1}$, Antonella Fusari ${ }^{2}$, Elisabetta Barocelli ${ }^{1}$ \\ and Simona Bertoni ${ }^{1 *}$
}

${ }^{1}$ Food and Drug Department, University of Parma, Parma, Italy, ${ }^{2}$ Department of Veterinary Sciences, University of Parma, Parma, Italy

Besides their long-known critical role in embryonic growth and in cancer development and progression, erythropoietin-producing hepatocellular carcinoma type B (EphB) receptor tyrosine kinases and their ephrin-B ligands are involved in the modulation of immune responses and in remodeling and maintaining the integrity of the intestinal epithelial layer. These processes are critically involved in the pathogenesis of inflammatory-based disorders of the gut, like inflammatory bowel diseases (IBDs). Accordingly, our aim was to investigate the role of the EphB/ephrin-B system in intestinal inflammation by assessing the local and systemic effects produced by its pharmacological manipulation in 2,4,6-trinitrobenzenesulfonic acid (TNBS)(Th1-dependent model) and dextran sulphate sodium (DSS)- (innate response model) induced colitis in mice. To this purpose, we administered chimeric Fc-conjugated proteins, allegedly able to uni-directionally activate either forward (ephrin-B1-Fc) or reverse (EphB1-Fc) signaling, and the soluble monomeric EphB4 extracellular domain protein, that, simultaneously interfering with both signaling pathways, acts as EphB/ephrin-B antagonist.The blockade of the EphB/ ephrin-B forward signaling by EphB4 and EphB1-FC was ineffective against DSS-induced colitis while it evoked remarkable beneficial effects against TNBS colitis: it counteracted all the evaluated inflammatory responses and the changes elicited on splenic $T$ lymphocytes subpopulations, without preventing the appearance of a splice variant of ephrin-B2 gene elicited by the haptenating agent in the colon. Interestingly, EphB4, preferentially displacing EphB4/ephrin-B2 interaction over EphB1/ephrin-B1 binding, was able to promote Tumor Necrosis Factor alpha (TNF $\alpha$ ) release by splenic mononuclear cells in vitro. On the whole, the collected results point to a potential role of the EphB/ephrin-B system as a pharmacological target in intestinal inflammatory disorders and suggest that the therapeutic efficacy of its blockade seemingly works through the modulation of immune responses, independent of the changes at the transcriptional and translational level of EphB4 and ephrin-B2 genes.

Keywords: TNBS-induced colitis, DSS experimental colitis, splenocytes culture, ephrin-B2, EphB4, EphB1-Fc 


\section{INTRODUCTION}

Eph receptors (erythropoietin-producing hepatocellular carcinoma) belong to the largest family of tyrosine kinases receptors (RTKs), divided in A (EphA1-8, 10) and B classes (EphB1-4, 6), according to structural features and binding affinities for their ligands, cell surface-bound ephrins (Eph receptors interacting proteins) (Pasquale, 2005). Eph receptors interact with ephrins on neighboring cells, generating cell contact-dependent bidirectional signaling that affects both the Eph- and the ephrinbearing cells (Lodola et al., 2017). Specifically, forward signaling is activated in Eph-bearing cells by ephrin binding, whereas reverse signaling is activated in ephrin-bearing cells by Eph binding (Barquilla and Pasquale, 2015).

The Eph/ephrin signaling regulates a wide range of cellular functions, encompassing cell proliferation and survival, cell shape, and migration (Kania and Klein, 2016). Besides its long known critical role in embryonic growth and in cancer development and progression, recent findings have highlighted its involvement in cell adhesion-based responses, in the modulation of immune responses, and in remodeling and maintaining the integrity of the epithelial layer (Funk and Orr, 2013; Perez White and Getsios, 2014). In particular, the interaction between EphB4 on leukocytes and endothelial ephrin-B2 regulates endothelial activation, leukocytes adhesion, and transmigration (Pfaff et al., 2008); moreover, ephrin-B1, ephrin-B2, and EphB4 are involved in T-cell development and activation (Kawano et al., 2012; Jin et al., 2014), in the organization of stem cell compartments and in the ordered migration of epithelial cells along the intestinal villus axis (Perez White and Getsios, 2014). Collectively, the EphB/ephrin-B system appears to affect several cellular targets critically involved in the pathogenesis of inflammatory-based disorders, like inflammatory bowel diseases (IBDs).

IBDs are chronic inflammatory disorders of the gastrointestinal (GI) tract, characterized by an aberrant immune response against luminal antigens. Crohn's disease (CD) and ulcerative colitis (UC) are the two principal types of IBD: they show a relapsing-remitting course and are characterized by impaired intestinal epithelial barrier and abnormal $\mathrm{T}$-cell responses (Kaser et al., 2010). Interestingly, the expression of B-type Eph/ ephrins in IBD patients is altered: in particular, ephrin-B2 messenger RNA (mRNA) is over-expressed in the gut mucosal lesions of CD patients (Hafner et al., 2005).

Despite this intriguing preliminary evidence, the intervention of EphB/ephrin-B in colitis has remained basically unexplored till now. Hence, our primary aim was to investigate the role of EphB/ephrin-B system in intestinal inflammation by assessing the local and systemic effects produced by pharmacological manipulation of EphB/ephrin-B pathway in two distinct chemically induced murine models of IBD: acute 2,4,6-trinitrobenzenesulfonic acid (TNBS)-induced colitis, a Th1-mediated model of intestinal inflammation, and dextran sulphate sodium (DSS)-induced colitis, characterized primarily by activation of innate immune responses (Kiesler et al., 2015). To this purpose, we administered chimeric Fc-conjugated
TABLE 1 | Purported functional effects of administered recombinant proteins ephrin-B1-Fc, EphB1-Fc, and EphB4.

\begin{tabular}{llcc}
\hline $\begin{array}{l}\text { Recombinant } \\
\text { protein }\end{array}$ & Target & \multicolumn{2}{c}{ Effects } \\
\cline { 3 - 4 } & & $\begin{array}{c}\text { Forward } \\
\text { signaling }\end{array}$ & $\begin{array}{c}\text { Reverse } \\
\text { signaling }\end{array}$ \\
\hline ephrin-B1-Fc & EphB & $\uparrow$ & $\downarrow$ \\
EphB1-Fc & ephrin-B & $\downarrow$ & $\uparrow$ \\
EphB4 & ephrin-B & $\downarrow$ & $\downarrow$ \\
\hline
\end{tabular}

$\uparrow$, Increased; $\downarrow$, Decreased.

Adapted from Barquilla and Pasquale, 2015.

proteins-allegedly able to uni-directionally activate forward signaling and to block the reverse one (ephrin-B1-Fc), or vice versa, to activate reverse signaling and to block the forward one (EphB1-Fc) (Barquilla and Pasquale, 2015) — and soluble EphB4 extracellular domain, which, being a monomer devoid of Fc fragment, is reported to simultaneously interfere with both forward and reverse signaling pathways and to behave as EphB/ephrin-B antagonist (Kertesz et al., 2006). The supposed functional effects of the administered recombinant proteins are reported in Table $\mathbf{1}$ for the sake of clarity. As indicators of colitis severity, we evaluated both clinical and inflammatory markers in mice exposed to TNBS or DSS. Moreover, to assess whether the intestinal inflammatory process induced by TNBS and the beneficial action, provided by monomeric EphB4, were associated with changes in the expression levels of ephrin-B2 and of its preferential ligand EphB4 in the colon, their mRNA and protein levels were determined in normal mice and in vehicle- and drugs-treated colitic mice. Finally, to clarify the mechanism of action of the EphB/ephrin-B antagonist, we tested the effects of monomeric EphB4 on the activation of splenic mononuclear cells through in vitro assays.

\section{MATERIALS AND METHODS}

\section{Animals}

Female C57BL/6 mice (8-12 weeks old) (Charles River Laboratories, Calco, Italy), weighing 20 to $24 \mathrm{~g}$, were housed five per cage in identical conditions at least 7 days before experiment started. They were maintained under standard conditions at our animal facility $\left(12: 12 \mathrm{~h}\right.$ light-dark cycle, $22^{\circ} \mathrm{C}$ to $24^{\circ} \mathrm{C}$, food and water available ad libitum). All the experimental procedures and suppression by $\mathrm{CO}_{2}$ inhalation were performed between 9:00 AM and 12:00 AM. All appropriate measures were taken to minimize pain or discomfort of animals. Animal experiments were performed according to the guidelines for the use and care of laboratory animals, and they were authorized by the local Animal Care Committee "Organismo Preposto al Benessere degli Animali" and by Italian Ministry of Health "Ministero della Salute" (DL 26/2014). Animal studies were reported in compliance with the Animal Research: Reporting of In Vivo Experiments (ARRIVE) guidelines (Bramhall et al., 2015). 


\section{Induction of Colitis}

Seven days before intrarectal (i.r.) instillation, animals were subjected to skin sensitization through cutaneous application of $50 \mu \mathrm{l}$ of a $10 \%(\mathrm{w} / \mathrm{v})$ TNBS solution in $50 \%$ ethanol. After $20 \mathrm{~h}$ of fasting with free access to water containing $5 \%$ glucose, a 10-cm-long PE-50 tubing attached to a tuberculin syringe was inserted $4 \mathrm{~cm}$ into the anus of mice. The i.r. administration of the same volume and concentration of TNBS solution applied during skin sensitization was performed in anaesthetised mice (isoflurane 2\%) kept in a vertical head-down position for $3 \mathrm{~min}$ to avoid leakage of the intracolonic instillate. Animals were suppressed by $\mathrm{CO}_{2}$ inhalation three days after TNBS instillation. The TNBS-induced colitis model with previous skin sensitization was chosen to reproduce a model of colitis characterized by the prominent activation of the adaptive immune system (te Velde et al., 2006).

DSS colitis was induced by free access to $3 \% \mathrm{w} / \mathrm{v}$ DSS (MW, $36-50 \mathrm{kDa}$ ) solution in drinking water for 5 days. Animals were suppressed by $\mathrm{CO}_{2}$ inhalation on day 8 (Waldner and Neurath, 2009).

\section{Experimental Design}

Pharmacological treatments started $8 \mathrm{~h}$ after the exposure to the colitogenic agent (TNBS i.r.; DSS in drinking water) and were applied for 3 days in TNBS colitis and for 5 days in DSS colitis.

Mice were assigned through block randomization to the normal group $(\mathrm{N})$, comprising mice intra-rectally inoculated with $50 \mu \mathrm{l}$ $0.9 \% \mathrm{NaCl}$ (saline solution) (for TNBS colitis, $n=30$ ) or receiving drinking water (for DSS colitis, $n=15$ ) and administered $10 \mathrm{~mL} /$ $\mathrm{kg} /$ day saline subcutaneously (s.c.), or to the following experimental groups of colitic mice: saline [CNT, $10 \mathrm{~mL} / \mathrm{kg}$ s.c., $n=20$ (DSS); $n=40$ (TNBS)], EphB1-Fc [30 $\mu \mathrm{g} / \mathrm{kg}$ s.c., $n=6$ (DSS); $n=10$ (TNBS)], ephrin-B1-Fc [17 $\mu \mathrm{g} / \mathrm{kg}$ s.c., $n=5$ (DSS and TNBS)], EphB4 [20 $\mu \mathrm{g} / \mathrm{kg}$ s.c., $n=6$ (DSS); $n=15$ (TNBS)], IgG1-Fc (10 $\mu \mathrm{g} /$ $\mathrm{kg}$ s.c., $n=6$ (negative control for TNBS)], cyclosporine A (CsA) [25 $\mathrm{mg} / \mathrm{kg} /$ die intraperitoneal (i.p.), $n=7$ (positive control for DSS)]. Table 2 briefly resumes the characteristics of the experimental groups. The dosage and route of administration of EphB4 and CsA were chosen on the basis of preliminary experiments and previous investigations (Satoh et al., 2009), and doses of ephrinB1-Fc, EphB1-Fc, and IgG1-Fc equimolar to EphB4 were applied. The study was performed using experimental blocks composed by
10 or 12 mice that were randomly assigned to four or five groups of treatment ( $N$ and CNT were present in each experimental block), each one encompassing two animals.

Due to possible seasonal variability, $N$ and CNT mice were repeated periodically all over the study to verify the attainment of a constant degree of colitis severity with respect to physiological conditions, thus explaining the bigger size of $N$ and CNT experimental groups with respect to the other groups. Accordingly, each group of animals was randomly subdivided in two subgroups: colons excised from each subset was reserved either for histological analysis or for myeloperoxidase (MPO) activity determination, reverse transcription polymerase chain reaction (RT-PCR)/Western blotting assays, and for cytokine assays.

\section{Evaluation of Inflammatory Responses}

Disease Activity Index (DAI) was measured daily throughout the experimentation. Immediately after suppression, the macroscopic damage of colonic mucosa was assessed as macroscopic score (MS). The wet weight and the length of each colon were measured, and the weight/length ratio was considered as disease-related intestinal wall thickening. Colon, lungs, spleen, and mesenteric lymph nodes were collected for subsequent microscopic, biochemical, or flow cytometry analyses.

\section{Disease Activity Index (DAl)}

The severity of experimental colitis was estimated as DAI, a score assigned daily on the basis of body weight loss, stool consistency, and rectal bleeding, by unaware investigators in accordance to Cooper's modified method (Cooper et al., 1993). The scores were quantified as follows: stool consistency: 0 (normal), 1 (soft), 2 (liquid); body weight loss: $0(<5 \%), 1$ (5-10\%), $2(10-15 \%)$, 3 (15-20\%), 4 (20-25\%), 5 (>25\%); rectal bleeding: 0 (absent), 1 (light bleeding), 2 (heavy bleeding).

\section{Macroscopic Damage of Colonic Mucosa (MS)}

After suppression, the colon was explanted, opened longitudinally, gently flushed with saline solution, and MS was assessed through examination of the mucosa by an investigator unaware of the treatments applied. MS was determined according to previously published criteria (Rapalli et al., 2016) as the sum of scores ( $\max =$ 12) attributed as follows: presence of strictures and hypertrophic zones ( 0 , absent; 1 , one stricture; 2 , two strictures; 3 , more than

TABLE 2 | Experimental design with characteristics of each experimental group.

\begin{tabular}{|c|c|c|c|c|c|c|}
\hline \multirow[t]{2}{*}{ Groups } & \multicolumn{3}{|c|}{ TNBS colitis } & \multicolumn{3}{|c|}{ DSS colitis } \\
\hline & Colitogenic agent & Treatment & $\mathbf{N}$ & Colitogenic agent & Treatment & $\mathbf{N}$ \\
\hline $\mathrm{N}$ & Saline & Saline s.c. & 30 & Water & Saline s.c. & 15 \\
\hline CNT & TNBS & Saline s.c. & 40 & DSS & Saline s.c. & 20 \\
\hline EphB1-Fc & TNBS & EphB1-Fc s.c. & 10 & DSS & EphB1-Fc s.c. & 6 \\
\hline Ephrin-B1-Fc & TNBS & Ephrin-B1-Fc s.c. & 5 & DSS & Ephrin-B1-Fc s.c. & 5 \\
\hline EphB4 & TNBS & EphB4 s.c. & 15 & DSS & EphB4 s.c. & 6 \\
\hline IgG1-Fc & TNBS & lgG1-Fc s.c. & 6 & DSS & n.d. & n.d. \\
\hline CsA & TNBS & n.d. & n.d. & DSS & Cyclosporine A i.p. & 7 \\
\hline
\end{tabular}

N, number of mice in each experimental group; n.d., not determined; TNBS, 2,4,6-trinitrobenzenesulfonic acid; DSS, dextran sulphate sodium; s.c., subcutaneously administered; i.p., intraperitoneally administered. 
two strictures), mucus (0, absent; 1 , present), adhesion areas between the colon and other intra-abdominal organs ( 0 , absent; 1, 1 adhesion area; 2, 2 adhesion areas; 3, more than 2 adhesion areas), intraluminal hemorrhage ( 0 , absent; 1 , present), erythema ( 0 , absent; 1 , presence of a crimsoned area $<1 \mathrm{~cm}^{2} ; 2$, presence of a crimsoned area $>1 \mathrm{~cm}^{2}$ ), and ulcerations and necrotic areas ( 0 , absent; 1 , presence of a necrotic area $<1 \mathrm{~cm}^{2} ; 2$, presence of a necrotic area $>1 \mathrm{~cm}^{2}$ ).

\section{Colonic Length and Thickness}

The length of colon and its weight were measured to assess deposition of fibrotic material and muscular contraction elicited by colitis induction; weight/length ratio was calculated to assess colon thickness, according to previously published criteria (Grandi et al., 2017).

\section{Colonic and Pulmonary Myeloperoxidase (MPO) Activity Assay}

MPO activity, a marker of tissue granulocytes accumulation, was determined as described elsewhere (Vivo et al., 2017). Briefly, colonic and lung samples were weighed and homogenized in icecold potassium phosphate buffer $(100 \mathrm{mM}, \mathrm{pH}$ 7.4) containing $1 \mu \mathrm{g} / \mathrm{mL}$ aprotinin and centrifuged for $20 \mathrm{~min}$ at $12,500 \mathrm{RCF}$ at $4^{\circ} \mathrm{C}$. Pellets were re-homogenized in five volumes of ice-cold potassium phosphate buffer $(50 \mathrm{mM}, \mathrm{pH}$ 6) containing $0.5 \%$ hexadecylthrimethyl-ammoniumbromide (HTAB) and $1 \mu \mathrm{g} / \mathrm{mL}$ aprotinin. Then, samples went through three cycles of freezing and thawing and were centrifuged for $30 \mathrm{~min}$ at 15,500 RCF at $4^{\circ} \mathrm{C} .100 \mu \mathrm{L}$ of the supernatant was allowed to react with $900 \mu \mathrm{L}$ of a buffer solution containing $0.167 \mathrm{mg} / \mathrm{mL}$ o-dianisidine and $0.0005 \% \mathrm{H}_{2} \mathrm{O}_{2}$. Each assay was performed in duplicate, and the rate of change in absorbance was measured spectrophotometrically at $470 \mathrm{~nm}$ (Jenway, mod. 6300, Dunmow, Essex, England). The sensitivity of the assay was $10 \mathrm{mU} / \mathrm{mL}, 1$ unit of MPO being defined as the quantity of enzyme degrading $1 \mu \mathrm{mol}$ of peroxide per minute at $25^{\circ} \mathrm{C}$. Data were normalized with edema values [(wet weight - dry weight)/dry weight] (Moore-Olufemi et al., 2005) and expressed as U/g of dry weight tissue.

\section{Colonic Interleukin-1 $\beta$ Levels}

In $\mathrm{N}, \mathrm{CNT}$ and EphB4-treated mice exposed to TNBS, colonic interleukin-1 $\beta$ (IL-1 $\beta$ ) levels were determined using a commercially available Enzyme-Linked ImmunoSorbent Assay (ELISA) kit (IL-1 $\beta$ Mouse SimpleStep ELISA ${ }^{\mathrm{TM}}$ kit; Abcam Biochemicals $^{\mathrm{TM}}$, Cambridge, UK). Samples were homogenized for $1 \mathrm{~min}$ in $700 \mu \mathrm{L}$ of extraction buffer in accordance to the manufacturer's protocols. Samples were then centrifuged for 30 min at 14,000 RCF, and the supernatant was collected. Total protein concentration was quantified using Pierce bicinchoninic acid (BCA) protein assay kit (ThermoFisher Scientific Inc., Waltham, MA, USA). Colonic concentrations of IL- $1 \beta$ were determined in duplicate in 100 $\mu \mathrm{L}$ samples: the absorbance was measured spectrophotometrically at $450 \mathrm{~nm}$ (TECAN Sunrise ${ }^{\mathrm{TM}}$ powered by Magellan $^{\mathrm{TM}}$ data analysis software, Mannedorf, Switzerland). The assays sensitivity for IL-1 $\beta$ was $5 \mathrm{pg} / \mathrm{mL}$. Results were expressed as $\mathrm{pg} / \mathrm{mg}$ protein.

\section{Colonic Histology}

Colonic samples were harvested from normal mice $(n=3)$ and TNBS-treated animals administered with saline $(n=3)$ or EphB4 $(n=4)$, immersion-fixed in $10 \%$ neutral buffered formalin overnight, dehydrated, and embedded in paraffin. For each sample, at least five transverse $5-\mu \mathrm{m}$ sections were cut in the distal colon, stained with hematoxylin-eosin, and blindly examined in a light microscope (Nikon Eclipse E800). The histological damage was quantified using Bischoff's modified method (Bischoff et al., 2009): the grade of mucosal destruction ( 0 , normal; 1 , mild; 2 , moderate; 3 , severe) and the degree of leukocytes infiltration in the lamina propria and submucosa ( 0 , absent; 1 , mild; 2 , pronounced) were scored (maximum total score: 7 ). The average value of histological score was determined for each colon, pooled with those determined for colons of the other animals in the same experimental group, and the mean value \pm SEM was calculated.

\section{Evaluation of EphB4 and Ephrin-B2 Expression}

Reverse Transcription Polymerase Chain Reaction (RT-PCR)

Total RNA was isolated from colonic samples of $N$ and TNBSinduced colitic mice, either treated with saline or EphB4, through Qiagen RNeasy Protect Mini Kit (Qiagen, Hilden, DE) and quantified using Nanodrop ND-1000 (Thermo Fisher Scientific Inc, Waltham, MA). $1 \mu \mathrm{g}$ of RNA was reverse transcribed into complementary DNA (cDNA) and amplified using OneStep RT-PCR kit (Qiagen, Hilden, DE), according to the manufacturer's protocol. The following primer pairs, purchased by Life Technologies Italia (Monza, MB, Italy), were used:

- ephrin-B2, 5' -ACCCACAGATAGGAGACAAA-3' (forward),

- 5'-GGTTGATCCAGCAGAACTTG-3' (reverse);

- EphB4, 5' -AGCCCCAAATAGGAGACGAG-3' (forward),

- 5'-GGATAGCCCATGACAGGATC-3' (reverse);

- GAPDH, 5'-GACTCCACTCACGGCAAATT-3' (forward), - 5'-TCCTCAGTGTAGCCCAAGAT-3' (reverse).

PCR was conducted for 36 cycles to amplify EphB4 and ephrin-B2 sequences according to Ogawa et al. (2006). The following conditions were used for amplification: EphB4: denaturation for $10 \mathrm{~s}$ at $94^{\circ} \mathrm{C}$, annealing for $45 \mathrm{~s}$ at $53^{\circ} \mathrm{C}$, and extension for $3 \mathrm{~min}$ at $68^{\circ} \mathrm{C}$; ephrinB2: denaturation for $45 \mathrm{~s}$ at $94^{\circ} \mathrm{C}$, annealing for $45 \mathrm{~s}$ at $53^{\circ} \mathrm{C}$, and extension for $90 \mathrm{~s}$ at $72^{\circ} \mathrm{C}$. PCR products were separated on $1 \%$ agarose gels, visualized with a ChemiDoc ${ }^{\mathrm{TM}}$ Imaging System (Bio-Rad, Berkeley, CA, USA) after staining with RedSafe ${ }^{\mathrm{TM}}$ (iNtRON Biotechnology, Seongnam, South Korea) and analyzed by means of Image Lab ${ }^{\mathrm{TM}}$ software, Bio-Rad Laboratories, Inc. version 6.0. Expression levels of EphB4 and ephrin-B2 mRNAs were determined from four to seven independent samples after normalization by reference to the signal intensity of the band of Glyceraldehyde3-phosphate dehydrogenase (GAPDH) mRNA (PCR for 30 cycles, denaturation for $45 \mathrm{~s}$ at $94^{\circ} \mathrm{C}$, annealing for $45 \mathrm{~s}$ at $93^{\circ} \mathrm{C}$, and extension for $90 \mathrm{~s}$ at $72^{\circ} \mathrm{C}$ ) obtained in the same specimen. 


\section{Western Blotting}

Tissue lysates, obtained from colonic specimens excised from $\mathrm{N}$, CNT, and EphB4 TNBS-treated mice, were subjected to sodium dodecyl sulfate polyacrylamide gel electrophoresis (SDS-PAGE). Gels were then electro-blotted onto a nitrocellulose membrane (Bio-Rad, Hercules, CA) using a semi-dry transfer apparatus (Thermo Fisher Scientific Inc, Waltham, MA) containing a mixture of tris-glycine transfer buffer and $20 \%$ methanol. The nitrocellulose membranes were then incubated in blocking buffer (bovine serum albumin 5\%) for $1 \mathrm{~h}$ at room temperature and incubated overnight at $4^{\circ} \mathrm{C}$ with primary antibodies against EphB4 (catalog number: 20883-1-AP, lot number 00016411, Proteintech, Manchester, UK), ephrin-B2 (catalog number NBP1-84830, Novus Biologicals, Littleton, CO, USA) and $\beta$-actin (catalog number MA5-15739BTIN, lot number RB233172, Thermo Fisher Scientific Inc, Waltham, MA). After washing three times with tris-buffered saline, the membranes were incubated with horseradish peroxidaseconjugated secondary antibodies (Thermo Fisher Scientific Inc, Waltham, MA) for $1 \mathrm{~h}$ at room temperature. Protein bands were visualized using a chemiluminescence detection kit (Thermo Fisher Scientific Inc, Waltham, MA) and analyzed through C-DiGit Blot Scanner (Li-Cor, Nebraska, USA). The signal intensity of each band of EphB4 and ephrin-B2 was normalized to the signal intensity of the band of $\beta$-actin obtained in the same lane.

\section{Flow Cytometry Assays}

Isolation of Splenocytes

After suppression, the spleen from $N$, CNT (TNBS and DSS), and EphB4 (TNBS) mice was removed, mechanically dispersed through a $100-\mu \mathrm{m}$ cell strainer, and washed with PBS containing $0.6 \mathrm{mM}$ Ethylenediaminetetraacetic acid (EDTA) (PBS-EDTA). The cellular suspension was then centrifuged at 1,500 RCF for 10 min at $4^{\circ} \mathrm{C}$, the pellet re-suspended in PBS-EDTA, incubated with $2 \mathrm{~mL}$ of $\mathrm{NH}_{4} \mathrm{Cl}$ lysis buffer $\left(0.15 \mathrm{M} \mathrm{NH}_{4} \mathrm{Cl}, 1 \mathrm{mM} \mathrm{KHCO}, 0.1\right.$ $\mathrm{mM}$ EDTA in distilled water) for $5 \mathrm{~min}$, in the dark, to provoke erythrocytes lysis and centrifuged at $1,500 \mathrm{RCF}$ for $10 \mathrm{~min}$ at $4^{\circ} \mathrm{C}$. Then, pellets were washed with PBS-EDTA and resuspended in $5-\mathrm{mL}$ cell staining buffer (PBS containing 0.5\% fetal calf serum (FCS) and $0.1 \%$ sodium azide). Finally, the cellular suspension was stained with fluorescent antibodies (Kruisbeek et al., 2001).

\section{Isolation of Mesenteric Lymph Nodes (MLN)}

After suppression, harvesting of the whole MLN chain located in the mesentery of proximal colon was performed in $N$, CNT (TNBS and DSS) and EphB4 (TNBS) mice. The explanted tissue was rinsed with PBS, vascular and adipose tissues were removed to isolate MLN, mechanically dispersed through a $100-\mu \mathrm{m}$ cellstrainer, and washed with Hank's Balanced Salt Solution (HBSS) containing 5\% FCS. The obtained suspension was centrifuged at 1,500 RCF for $10 \mathrm{~min}$ at $4^{\circ} \mathrm{C}$, the pellet was washed with HBSS containing 5\% FCS and re-suspended in 3-mL cell staining buffer. Finally, the cellular suspension was stained with fluorescent antibodies.

\section{Immunofluorescent Staining}

Prior to staining with antibodies, $200 \mu \mathrm{L}$ of cellular suspension was incubated with IgG1-Fc ( $1 \mu \mathrm{g} / 10^{6}$ cells) for $10 \mathrm{~min}$ in the dark at $4^{\circ} \mathrm{C}$ to block non-specific binding sites for antibodies. The following antibodies were used for fluorescent staining: Phycoerythrin-Cyanine 5 (PE-Cy5) conjugated anti-mouse CD3e $\left(0.25 \mu \mathrm{g} / 10^{6}\right.$ cells, catalog number $15-0031$, lot number B226301), fluorescein isothiocyanate (FITC) anti-mouse CD4 $\left(0.25 \mu \mathrm{g} / 10^{6}\right.$ cells, catalog number 100406 , lot number B210488), $\mathrm{PE}$ anti-mouse CD8a $\left(0.25 \mu \mathrm{g} / 10^{6}\right.$ cells, catalog number 100708 , lot number B190687). Cells were incubated with antibodies for $1 \mathrm{~h}$ in the dark at $4^{\circ} \mathrm{C}$, washed with PBS to remove excessive antibody, and suspended in cell staining buffer to perform flow cytometry analysis. The viability of the cellular suspension was determined through propidium iodide (PI) staining, a membrane impermeable fluorescent dye, excluded by viable cells, that binds to DNA emitting red fluorescence, thus resulting as a suitable marker for dead cells. Cells were incubated with PI $10 \mu \mathrm{g} / \mathrm{mL}$ for $1 \mathrm{~min}$ in the dark, at room temperature, and immediately subjected to flow cytometry analysis. Only $\mathrm{PI}^{-v e}$ cells were included in the analysis.

Samples were analyzed using InCyte ${ }^{\mathrm{TM}}$ software (Merck Millipore, Darmstadt, Germany). Cell populations were defined as follows: lymphocytes gated in the Forward Scatter (FSC)-Side Scatter (SSC) plot (FSC low: SSC low); T lymphocytes (CD3 ${ }^{+}$lymphocytes); $\mathrm{CD} 4^{+}$helper $\mathrm{T}$ lymphocytes $\left(\mathrm{CD}^{+}{ }^{+} \mathrm{CD} 4^{+} \mathrm{CD}^{-}\right.$lymphocytes); $\mathrm{CD}^{+}$cytotoxic $\mathrm{T}$ lymphocytes (CD3 ${ }^{+} \mathrm{CD}^{+}{ }^{+} \mathrm{CD}^{-}$lymphocytes). Percentages were reported to the total number of splenocytes or MLN cells of each mouse to calculate the number of cells per population.

\section{In Vitro Assays \\ Mononuclear Cells Culture}

Spleens were removed from $\mathrm{N}$ mice, and splenocytes were isolated as previously described. Splenocytes suspensions were subjected to $40 \%$ to $80 \%$ Percoll $^{\circledR}$ (GE-Healthcare, Chicago, IL, USA) density gradient centrifugation. Cells were spun at 1000 RCF for $20 \mathrm{~min}$ at $20^{\circ} \mathrm{C}$, and mononuclear cells, comprising lymphocytes and monocytes, were collected from the $40 \%$ to $80 \%$ interface, washed with RPMI-1640 (EuroClone, Pero, MI, Italy), and resuspended in medium containing heat-inactivated $10 \%$ fetal bovine serum (FBS) (Gibco, Carlsbad, CA, USA) (Kruisbeek, 2001). Before being cultured, the percentage of splenic mononuclear cells represented by $\mathrm{CD}^{+}$cells was assessed by flow cytometry as previously described (see Immunofluorescent Staining).

Cells were then plated at $1.0^{\star} 10^{6}$ cells $/ \mathrm{mL}$ in 24 -well plates and cultured for $24 \mathrm{~h}$ at $37^{\circ} \mathrm{C}$ in a humidified atmosphere with $5 \% \mathrm{CO}_{2}$ in the absence or presence of EphB4 10 to $100 \mathrm{ng} / \mathrm{mL}$ or cyclosporin A (CsA) $1 \mu \mathrm{g} / \mathrm{mL}$, used as positive control. Ionomycin $(500 \mathrm{ng} / \mathrm{mL})$ and phorbol 12-myristate 13-acetate (PMA) $(50 \mathrm{ng} / \mathrm{mL})$ were added to the culture media in the final $4 \mathrm{~h}$ of incubation to stimulate cells (Li et al., 2015).

\section{Mononuclear Cells Viability by Trypan Blue Exclusion} Cell viability was assessed using a hemacytometer and the trypan blue assay by adding $100 \mathrm{ml}$ of cell suspension $\left(5.0^{\star} 10^{6}\right.$ cells $\left./ \mathrm{mL}\right)$ to $900 \mathrm{ml}$ of $0.4 \%$ trypan blue solution (Sigma). Ten microliters of each suspension were analyzed in a hemacytometer. Live and dead cells were enumerated under a light microscope. 
Percent viability was assessed at the time of isolation and after $24 \mathrm{~h}$ of incubation with vehicle, EphB4 10 to $100 \mathrm{ng} / \mathrm{mL}$ or CsA $1 \mu \mathrm{g} / \mathrm{mL}$ in the absence or presence of ionomycin and PMA (Klein et al., 2006).

\section{Determination of TNF- $\alpha$ Levels in Cultured Mononuclear Cells}

At the end of the incubation period with the test compounds and in the absence or presence of ionomycin and PMA, the culture media were frozen at $-80^{\circ} \mathrm{C}$ until cytokine measurement. TNF- $\alpha$ levels were determined in duplicate in $100 \mu \mathrm{L}$ samples, using a commercially available ELISA kit (Mouse TNF alpha ELISA Ready-SET-Go!, eBioscience ${ }^{\mathrm{TM}}$, San Diego, CA). The absorbance was measured spectrophotometrically at $450 \mathrm{~nm}$ (TECAN Sunrise $^{\mathrm{TM}}$ powered by Magellan ${ }^{\mathrm{TM}}$ data analysis software, Mannedorf, Switzerland). The assays sensitivity was $8 \mathrm{pg} / \mathrm{mL}$.

\section{ELISA Binding Assays}

ELISA assays were performed as previously described (Giorgio et al., 2019). Briefly, 96-well ELISA high binding plates (Costar, Corning, New York, NY, USA 9018) were incubated overnight at $4^{\circ} \mathrm{C}$ with $100 \mu \mathrm{L} /$ well of $1 \mu \mathrm{g} / \mathrm{mL}$ EphB1-Fc (R\&D systems, Minneapolis, MN, USA, 1596-B1) or EphB4-Fc (R\&D systems, Minneapolis, MN, USA, 446-B4) diluted in sterile phosphate buffered saline (PBS-0.2 g/L KCl, $8.0 \mathrm{~g} / \mathrm{L} \mathrm{NaCl}, 0.2 \mathrm{~g} / \mathrm{L} \mathrm{KH}_{2} \mathrm{PO}_{4}$, $1.15 \mathrm{~g} / \mathrm{L} \mathrm{Na}_{2} \mathrm{HPO}_{4}, \mathrm{pH}$ 7.4). The day after, wells were washed with washing buffer (PBS + 0.05\% tween20, pH 7.4) and blocked with $300 \mu \mathrm{l} /$ well with blocking solution (PBS $+0.5 \%$ BSA PanReac Applichem, Darmstadt, Germany A1391,0050) for $1 \mathrm{~h}$ at $37^{\circ} \mathrm{C}$. EphB4 (His Tag) (Sino Biological Inc., Beijing, China 50582$\mathrm{M} 08 \mathrm{H}$ ) was first incubated at 1 to $10,000 \mathrm{ng} / \mathrm{ml}$ with biotinylated ephrin-B1-Fc or ephrin-B2-Fc for $30 \mathrm{~min}$ at room temperature and then added to the wells at $37^{\circ} \mathrm{C}$ for $1 \mathrm{~h}$. Finally, wells were washed and incubated with $100 \mu \mathrm{L} /$ well Streptavidin-HRP (SigmaAldrich, Milan, Italy, S5512) for $20 \mathrm{~min}$ at room temperature, washed again and incubated at room temperature with $100 \mu \mathrm{l} /$ well $0.1 \mathrm{~g} / \mathrm{L}$ tetra-methylbenzidine (Sigma-Aldrich, Milan, Italy, 860336) reconstituted in stable peroxide buffer $(11.3 \mathrm{~g} / \mathrm{L}$ citric acid, 9.7 g/L sodium phosphate, $\mathrm{pH} 5.0)$, and $0.02 \% \mathrm{H}_{2} \mathrm{O}_{2}(30 \% \mathrm{w} / \mathrm{w}$ in water), added immediately before use. The reaction was stopped with $3 \mathrm{~N} \mathrm{HCl} 100 \mu \mathrm{L} /$ well, and the absorbance was measured using an ELISA plate reader (Sunrise, TECAN, Switzerland) at $450 \mathrm{~nm}$.

\section{Statistics}

All data were presented as means \pm SEM. Comparison among experimental groups was made using analysis of variance (oneway or two-way ANOVA) followed by Bonferroni's post-test, when $P<0.05$, chosen as level of statistical significance, was achieved. Non-parametric Kruskal-Wallis analysis, followed by Dunn's post-test, was applied for statistical comparison of MS. All analyses were performed using Prism 4 software (GraphPad Software Inc. San Diego, CA, USA).

\section{Drugs, Antibodies, and Reagents}

Recombinant rat EphB1-Fc chimera and recombinant mouse ephrinB1-Fc chimera were purchased from R\&D systems ${ }^{\mathrm{TM}}$
(Minneapolis, MN), mouse EphB4 (His Tag) from Sino Biological Inc. ${ }^{\mathrm{TM}}$ (Beijing, China). FITC anti-mouse CD4, $\mathrm{PE}$ anti-mouse $\mathrm{CD} 8$, and propidium iodide were purchased from BioLegend $^{\mathrm{TM}}$ (San Diego, CA, USA), PE-Cy5 anti-mouse CD3 from Affymetrix eBioscience ${ }^{\mathrm{TM}}$ (San Diego, CA) and IgG1-Fc from Millipore ${ }^{\mathrm{TM}}$ (Merck, Darmstadt, Germany). DSS was purchased from MP Biomedicals ${ }^{\circledR}$ (Germany). TNBS, cyclosporine A, ethanol, HTAB, hydrogen peroxide, and all the other reagents were purchased from Sigma Aldrich ${ }^{\mathrm{TM}}$ (St. Louis, MO, USA). Drugs were dissolved in saline solution (recombinant proteins) or carboxymethylcellulose $0.5 \%$ (CsA) the day of the experiment.

\section{RESULTS}

\section{Instillation of TNBS Evoked a Severe Inflammatory Response}

Compared with the $\mathrm{N}$ group, CNT mice showed a significantly higher DAI value (Figure 1A), caused by both body weight loss and softening of stools. Inoculation of the haptenating agent induced also a remarkable colonic shortening and thickening and injury of the mucosa, evaluated as MS (Figure 1B-D). Colonic and pulmonary myeloperoxidase activity was severely augmented upon colitis induction (Figure 1E and F) indicating a conspicuous recruitment of granulocytes within tissues. As a result, also colonic IL-1 $\beta$ levels were increased in CNT mice compared with the $N$ group $(N: 11.7 \pm 3.0 \mathrm{pg} / \mathrm{mg}$ proteins vs. CNT: $221.5 \pm 45.0 \mathrm{pg} / \mathrm{mg}$ proteins; $P<0.05)$. Microscopic histological analysis showed extensive mucosal necrosis and conspicuous granulocytes infiltration both in the lamina propria and in the submucosa in TNBS-exposed mice (Figure 2B; histological score: $6.0 \pm 0.6$; Figure 2D) compared with normal mice (Figure 2A; histological score: $0.3 \pm 0$; Figure 2D).

\section{EphB4 and EphB1-Fc Dampened TNBS-Induced Inflammatory Responses}

Colitic mice were subjected to repeated s.c. treatment with monomeric EphB4 protein or with Fc-conjugated chimeric proteins, containing equimolar doses of either ephrin-B1 or EphB1 ectodomains. EphB4 protein $20 \mu \mathrm{g} / \mathrm{kg}$ elicited protective effects against colitis: a marked reduction of DAI and of colonic macroscopic damage, thickness, and shortening occurred. Granulocyte infiltration within colon and lungs was deeply contrasted (Figure 1) and, similarly, colonic IL-1 $\beta$ levels were attenuated (87.52 \pm 15.16 vs. CNT: $221.49 \pm 44.96 \mathrm{pg} / \mathrm{mg}$ proteins), although no relevant protection against TNBS-induced intestinal injury emerged from the histological analysis (Figure 2C; histological score: $5.3 \pm 0.3$; Figure 2D). When tested at 5 and $10 \mu \mathrm{g} / \mathrm{kg}, \mathrm{EphB} 4$ showed dose-dependent effects, being able to counteract colonic shortening and thickening at $10 \mu \mathrm{g} / \mathrm{kg}$ (Supplementary Figure 1).

Similar to EphB4, EphB1-Fc $30 \mu \mathrm{g} / \mathrm{kg}$ consistently reduced DAI and MS, counteracted colonic shortening and thickening and dampened the increase of MPO levels in colon and lungs (Figure 1). On the other hand, mice treated with equimolar 


\section{TNBS-INDUCED COLITIS}

A Disease Activity Index

B

MS
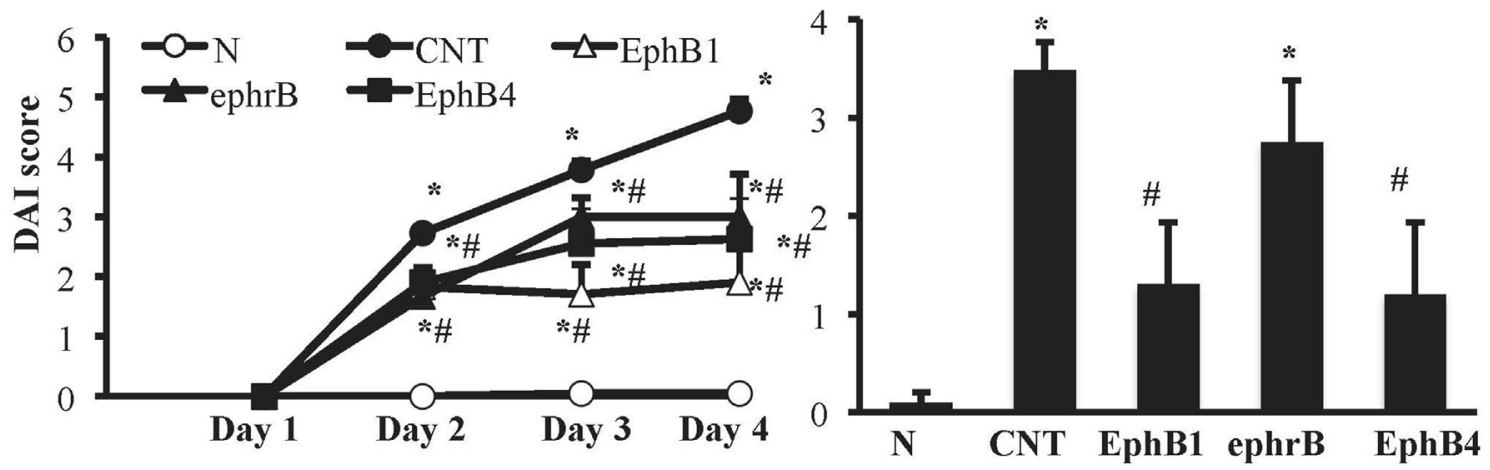

C

Colonic length

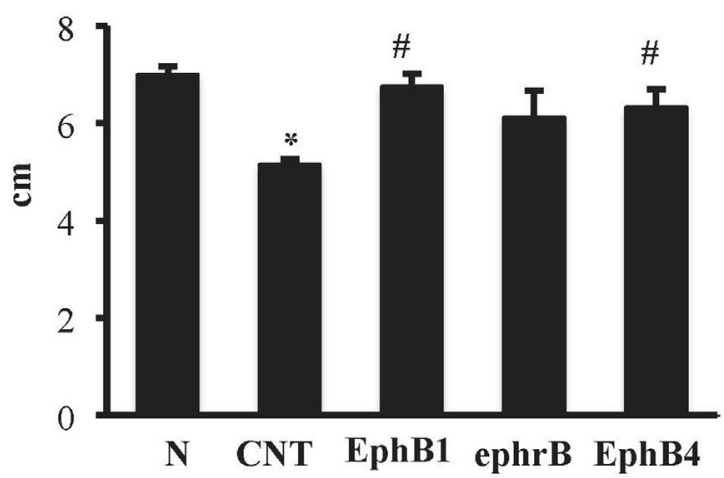

D

Colonic thickness
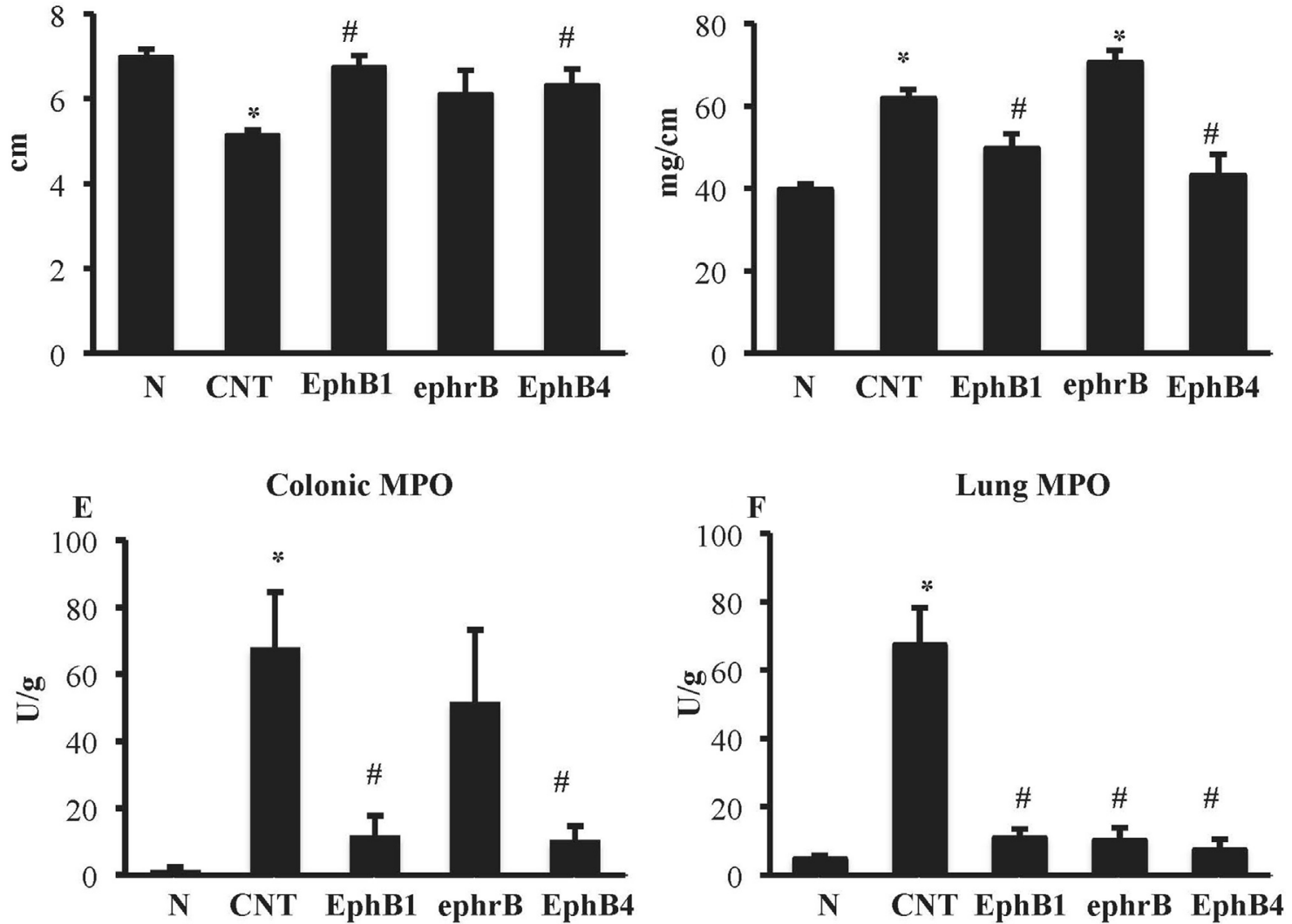

FIGURE 1 | Effects of EphB/ephrinB ligands on 2,4,6-trinitrobenzenesulfonic acid (TNBS)-induced inflammatory responses. Disease Activity Index (A), macroscopic score (B), colonic length (C), colonic thickness (D), colonic myeloperoxidase (MPO) (E), and lung MPO (F) activity assessed in vehicle-treated normal mice (N) and in TNBS-treated mice administered with vehicle (CNT), EphB1-Fc $30 \mu \mathrm{g} / \mathrm{kg}$ (EphB1), ephrin-B1-Fc $17 \mu \mathrm{g} / \mathrm{kg}($ ephrB), EphB4 $20 \mu \mathrm{g} / \mathrm{kg}(n=5-12$ independent values per group). ${ }^{\star} P<0.05$ vs. N mice; ${ }^{\#} P<0.05$ vs. CNT mice; one-way ANOVA followed by Bonferroni's post-test.

ephrinB1-Fc (17 $\mu \mathrm{g} / \mathrm{kg})$ showed MPO activity lower than controls only in lungs (Figure 1F).

Finally, treatment with IgG1-Fc $10 \mu \mathrm{g} / \mathrm{kg}$, tested as negative control, did not significantly modify any of the inflammatory parameters increased by TNBS enema, albeit for colonic length (Supplementary Table 1).

\section{DSS Administration Elicited a Severe Colitis Not Attenuated by EphB/EphrinB Modulation}

DSS administration caused severe colitis characterized by worsening of DAI score and of the local parameters of inflammation and damage: colon length was markedly decreased, whereas colon 
A

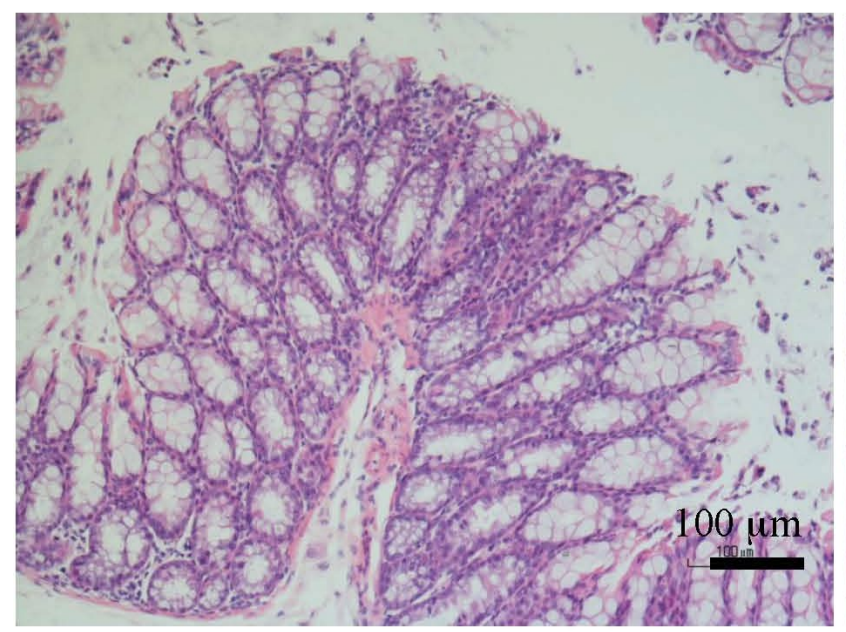

B

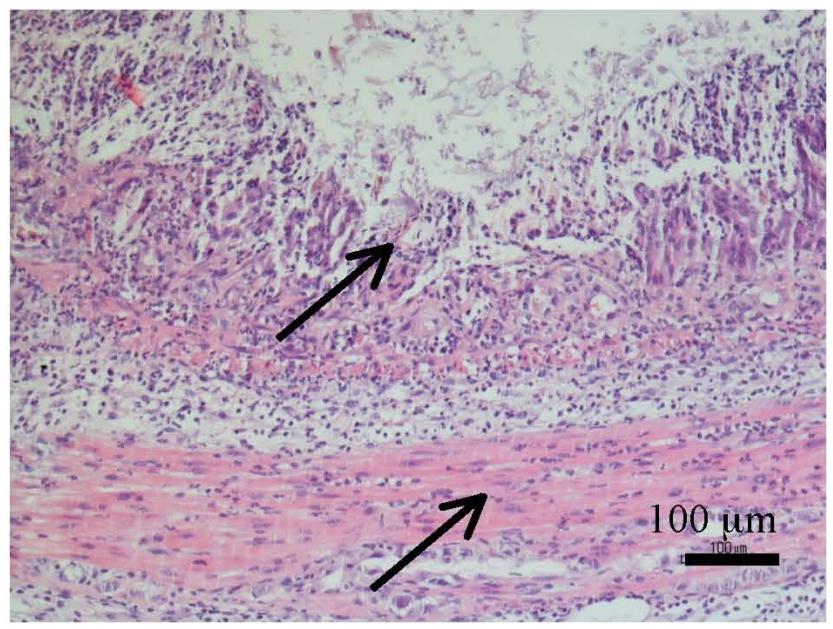

D

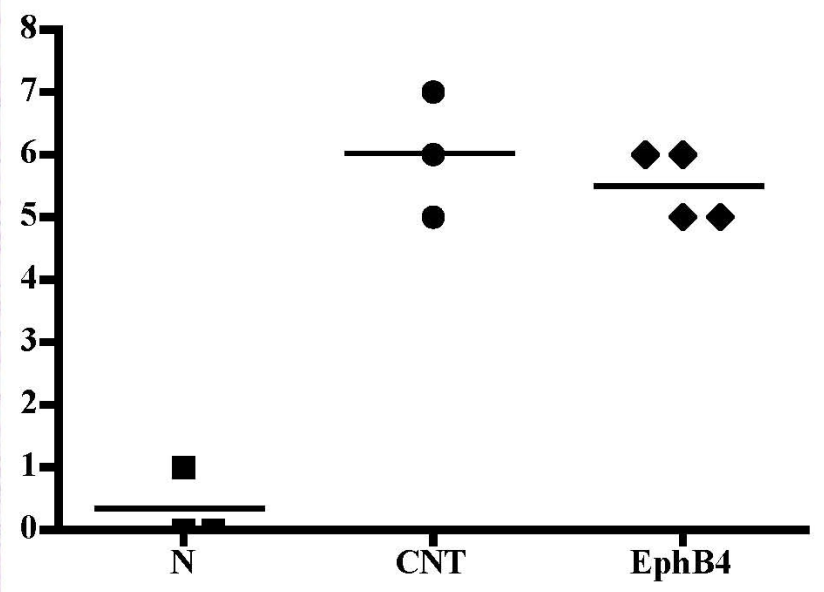

FIGURE 2 | Histology. Representative hematoxylin-eosin-stained sections of colonic specimens harvested from vehicle-treated normal mice (A) and from TNBStreated mice administered with vehicle (B) or EphB4 $20 \mu \mathrm{g} / \mathrm{kg}$ (C). TNBS colonic instillation caused mucosal necrosis, neutrophils infiltration, and submucosal edema (indicated by arrows) in vehicle-treated animals not attenuated in EphB4-treated mice (C). Panel D represents histological damage scoring of colonic sections obtained from vehicle-treated normal mice $(\mathbf{\bullet})$, CNT mice $(\bullet)$, or EphB4-treated colitic mice $(\bullet)$ (horizontal bar at the mean value).

thickness and colonic myeloperoxidase activity were significantly augmented. On the contrary, no mucosal lesions, assessed as MS, could be detected following DSS treatment. A huge infiltration of neutrophils was triggered in the lungs, indicating a strong systemic inflammation (Figure 3).

In the DSS model, neither the administration of Fc-conjugated agonists, EphB1-Fc, and ephrinB1-Fc nor the use of monomeric protein EphB4 were effective in controlling the burden of DSS-induced damage; on the contrary, interference with EphB/ ephrin-B signaling even worsened mice general clinical conditions (Figure 3). Only treatment with immunosuppressant cyclosporine A $25-\mathrm{mg} / \mathrm{kg}$ i.p., tested as positive control, was able to reduce DAI score at day $8(\mathrm{CsA} 0.3 \pm 0.2$ vs. CNT $2.9 \pm 0.3, P<0.05)$ and colonic neutrophils infiltration (MPO activity: CsA $19.3 \pm 5.0 \mathrm{U} / \mathrm{g}$ vs. CNT $42.9 \pm 3.7 \mathrm{U} / \mathrm{g}, P<0.05)$ with respect to control values, leaving unmodified the other responses (Figure 3).

\section{Treatment With EphB4 Did Not Influence Colonic EphB4 and Ephrin-B2 Genes Expression}

Colonic tissues of $\mathrm{N}$ mice showed single bands of EphB4 and ephrin-B2 (transcript X1) mRNA transcripts at 550 and 380 $\mathrm{bp}$, respectively. In CNT mice exposed to TNBS, the levels of EphB4 mRNA were unchanged with respect to $\mathrm{N}$ mice; as regard ephrin-B2, a second mRNA isoform appeared at $270 \mathrm{bp}$ 


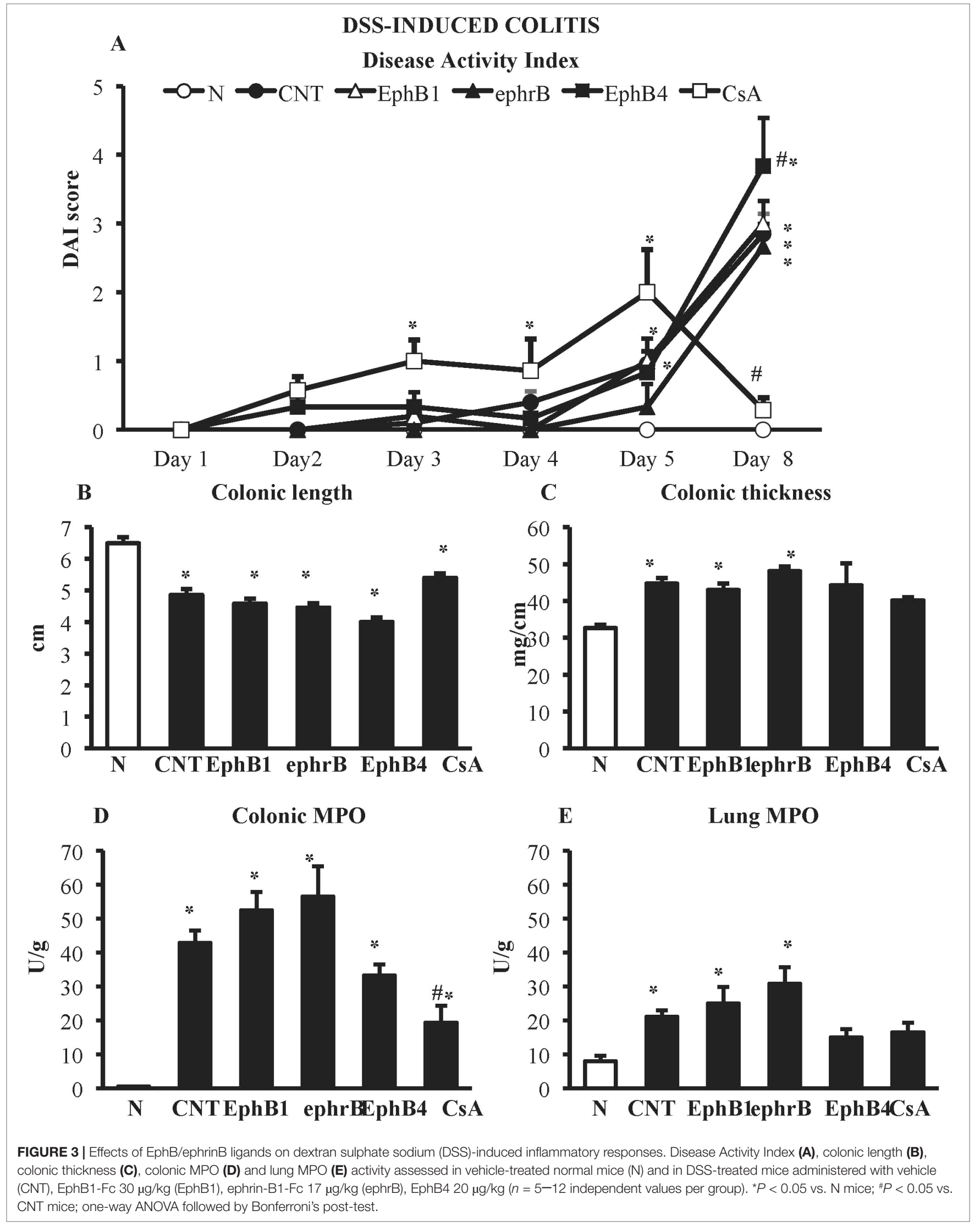


(transcript X2), not evident in $\mathrm{N}$ mice $(P<0.05$ vs. $\mathrm{N})$, whereas the levels of transcript X1 were slightly decreased. Sanger sequencing of ephrin-B2 cDNA (Microsynth AG, Switzerland) confirmed that the two bands corresponded to splice variants of ephrin-B2 gene differing by 93 bp. Treatment with EphB4 did not significantly change EphB4 or ephrin-B2 gene expression with respect to CNT group (Figure 4). As regard EphB4 and ephrin-B2 proteins expression in the colon, only single bands could be detected through Western blot analysis, and signal intensity was comparable in all groups (Figure 5).

\section{EphB4 Affects TNBS-Induced Changes in T-Cell Profile}

The phenotypic characterization of splenic and MLN T-cells was performed in $\mathrm{N}$ and CNT mice: TNBS instillation decreased $\mathrm{CD}^{+}$and $\mathrm{CD}^{+} \mathrm{T}$ cells in the spleen and in MLN (Figure 6). Interestingly, when we tested the effect of EphB4 treatment, the monomeric protein increased the number of $\mathrm{CD}^{+}$and especially of CD8 ${ }^{+} \mathrm{T}$ cells in the spleen, leaving unmodified MLN populations (Figure 6).

On the contrary, DSS exposure did not remarkably affect lymphocytes populations, the number of $\mathrm{CD}^{+}$and $\mathrm{CD}^{+} \mathrm{T}$ cells being essentially unaltered in either lymphoid tissues (Supplementary Figure 2).

\section{EphB4 Promoted TNF $\alpha$ Release From Splenic Mononuclear Cells}

The effects of EphB4 were also investigated in vitro on splenic mononuclear cell culture activation. Flow cytometry confirmed that around half of the isolated splenocytes set into culture were represented by $\mathrm{CD}^{+}$lymphocytes $(48.7 \% \pm$ $6.6 \%)$. Then, their viability was ascertained by trypan blue exclusion assay: in case the percentage of viable cells was higher than $95 \%$, cells were cultured, incubated with the test

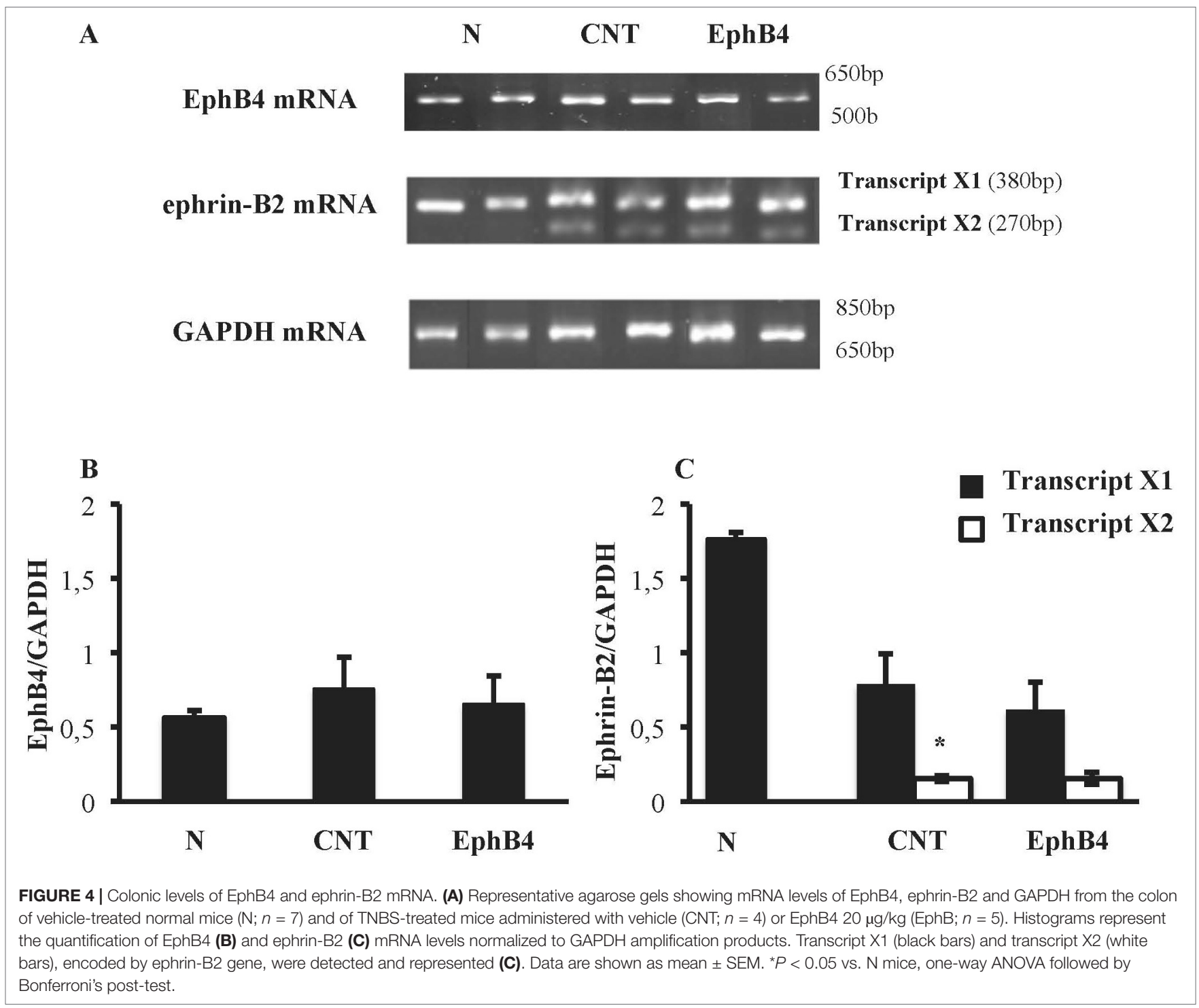


A
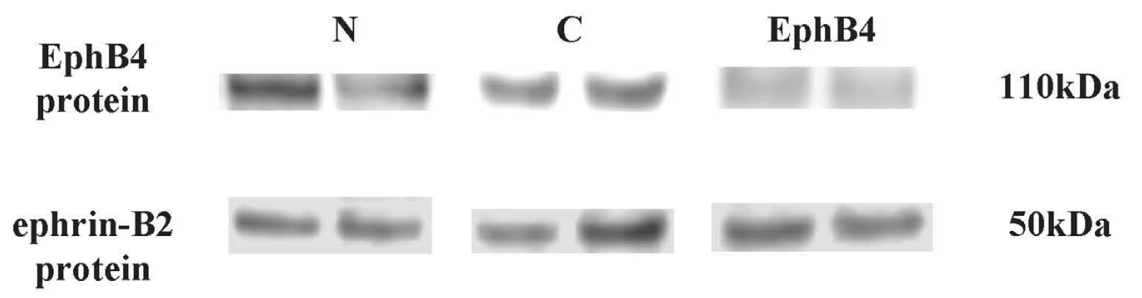

$\beta$-actin $42 \mathrm{kDa}$

B

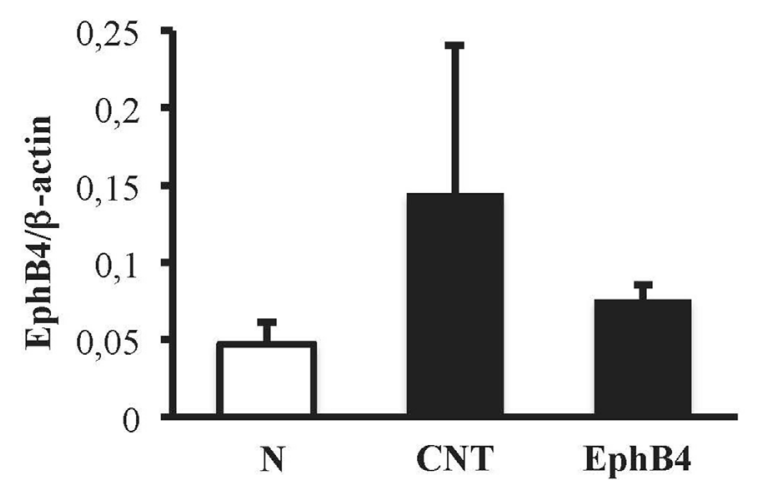

C

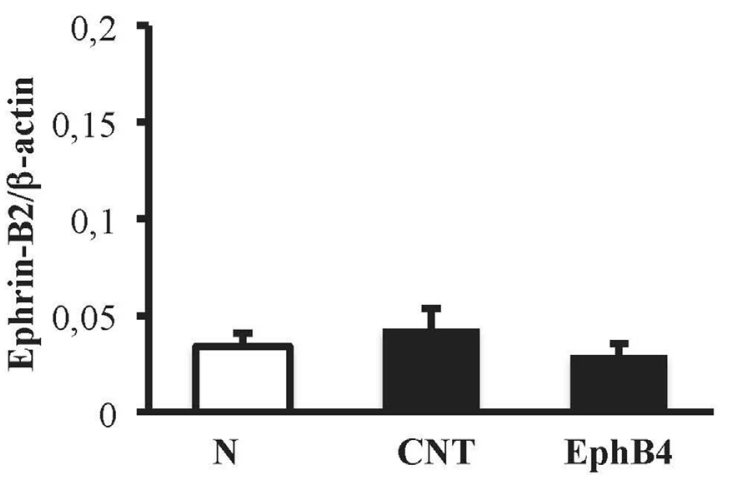

FIGURE 5 | Colonic levels of EphB4 and ephrin-B2 proteins. (A) Representative western blots showing the expression of EphB4, ephrin-B2 and $\beta$-actin proteins in lysates, obtained from the colon of vehicle-treated normal mice (N) and in TNBS-treated mice administered with vehicle (CNT) or EphB4 20 $\mu$ g/kg (EphB4).

Histograms represent the densitometric analysis of EphB4 (B) and ephrin-B2 (C) blots, normalized to $\beta$-actin ( $n=3-4$ per group).

compounds or vehicle, stimulated by PMA and ionomycin, and TNF- $a$ levels were determined in the cell culture media. After $24 \mathrm{~h}$ of incubation with vehicle, the vitality was maintained (Supplementary Table 2) and the cytokine levels were significantly augmented in stimulated cells compared with the unstimulated conditions (Figure 7). Cyclosporine A $1 \mu \mathrm{g} / \mathrm{ml}$ was able to abolish TNF- $\alpha$ release induced by PMA and ionomycin while maintaining lymphocytes viability. As regard the monomeric protein, at the higher tested concentration, EphB4 enhanced the increase of TNF-a levels raised by the stimulants, without affecting cells vitality (Figure 7 and Supplementary Table 2).

\section{Binding Affinity of Monomeric EphB4 to Ephrin-B1 and Ephrin-B2}

To assess the affinity profile of EphB4 towards ephrin-B1 and ephrin-B2 proteins, we immobilized the EphB1-Fc and EphB4-Fc ectodomains on ELISA plates and then promoted the binding of biotinylated ephrin-B1-Fc and ephrin-B2-Fc, respectively, according to a previously published protocol (Giorgio et al., 2019). Monomeric EphB4 was able to concentration-dependently displace both ephrin-B1-Fc/EphB1-Fc and ephrin-B2-Fc/ EphB4-Fc binding, but antagonized ephrin-B2-Fc/EphB4-Fc binding at concentrations more than 20 times lower than those interfering with ephrin-B1-Fc/EphB1-Fc interaction (Figure 8).

\section{DISCUSSION}

The multiplicity of cell targets, involved in inflammatory responses, affected by EphB/ephrin-B signaling pathways (Kania and Klein, 2016) and the documented up-regulation of ephrin-B2 mRNA levels in gut mucosal lesions of CD patients (Hafner et al., 2005) prompted us to focus our attention on the possible involvement of EphB/ephrin-B system in intestinal inflammatory disorders. To this end we applied two murine models of IBD characterized by complementary pathogenetic mechanisms: the TNBS model, primarily driven by Th1-mediated immune responses, and the DSS one, mainly triggered by innate immunity responses and useful to highlight the efficacy of agents able to re-establish the integrity of the epithelium after injury (Kiesler et al., 2015). In our experimental conditions, both TNBS and DSS acute exposures produced inflammatory responses of remarkable 

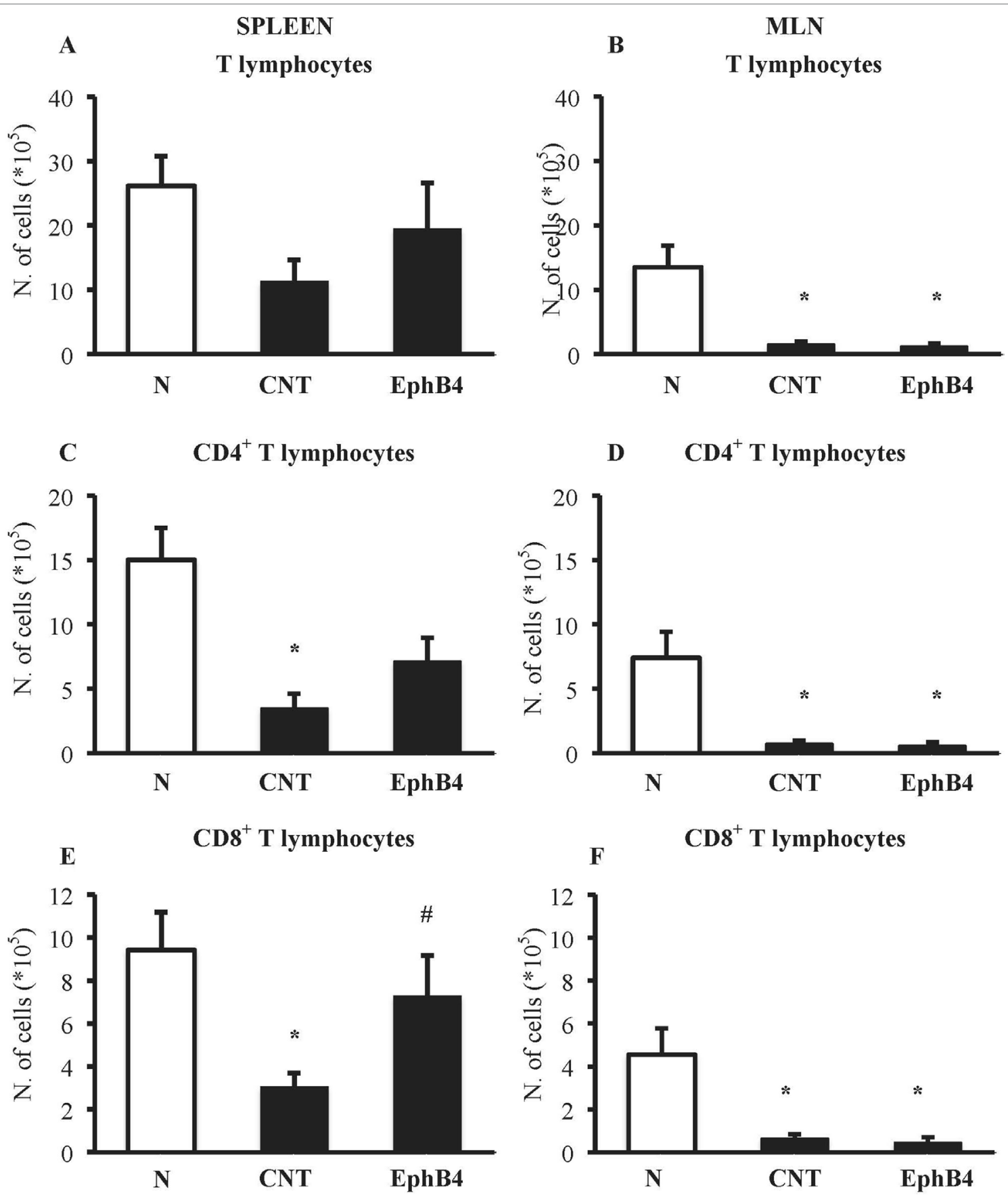

FIGURE 6 | EphB4 attenuated TNBS-induced changes in spleen T-cell profile. Number of T lymphocytes (CD3+) (A, B), CD4+ (C, D), and CD8+ (E, F) T lymphocytes in the spleen (A, C, E) and in MLN (B, D, F) excised from vehicle-treated normal mice (N) and TNBS-treated mice administered with vehicle (CNT) or EphB4 $20 \mu \mathrm{g} / \mathrm{kg}$ (EphB4) ( $n=5-9$ independent values per group). ${ }^{*} P<0.05$ vs. N mice; ${ }^{*} P<0.05$ vs. CNT mice, one-way ANOVA followed by Bonferroni's post-test.

intensity, with gradual impairment of general physical conditions, colonic mucosal injury, shortening and thickening, and abundant recruitment of colonic and pulmonary neutrophils. However, despite the analogies, the pharmacological manipulation of EphB/ephrin-B system produced distinct outcomes in the two models. Treatment with recombinant proteins was ineffective in attenuating DSS-induced colitis, only cyclosporine being able to mitigate clinical severity and colonic neutrophil recruitment; at variance, blockade of EphB/ephrin-B signaling markedly lowered both the local and systemic inflammatory responses elicited by TNBS, improving health conditions and counteracting colonic changes, leukocytes enrolment, and, accordingly IL-1 $\beta$ production. Specifically, overlapping results were obtained, on one side, by interfering with both forward and reverse signaling 


\section{TNF $\alpha$ levels}

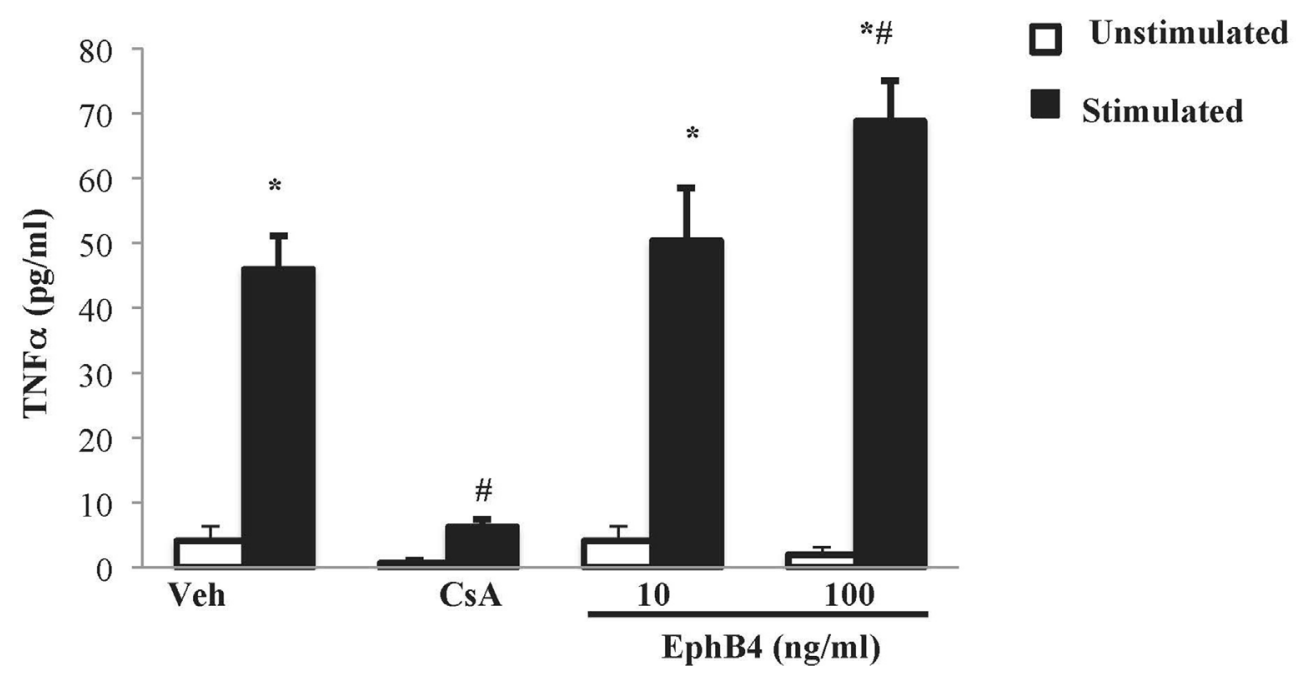

FIGURE 7 | Effects of EphB4 on splenic mononuclear cells activation. TNF $\alpha$ production by cultured splenic mononuclear cells incubated with vehicle (Veh), cyclosporine A $1 \mu \mathrm{g} / \mathrm{ml}$ (CsA) or EphB4 (10-100 ng/ml) (EphB4) in the presence (black bars) or absence (white bars) of PMA (50 ng/mL) and ionomycin (500 ng/mL) ( $n=4-10$ independent values per group). ${ }^{*} P<0.05$ vs. unstimulated; ${ }^{*} P<0.05$ vs. corresponding vehicle; two-way ANOVA followed by Bonferroni's post-test.

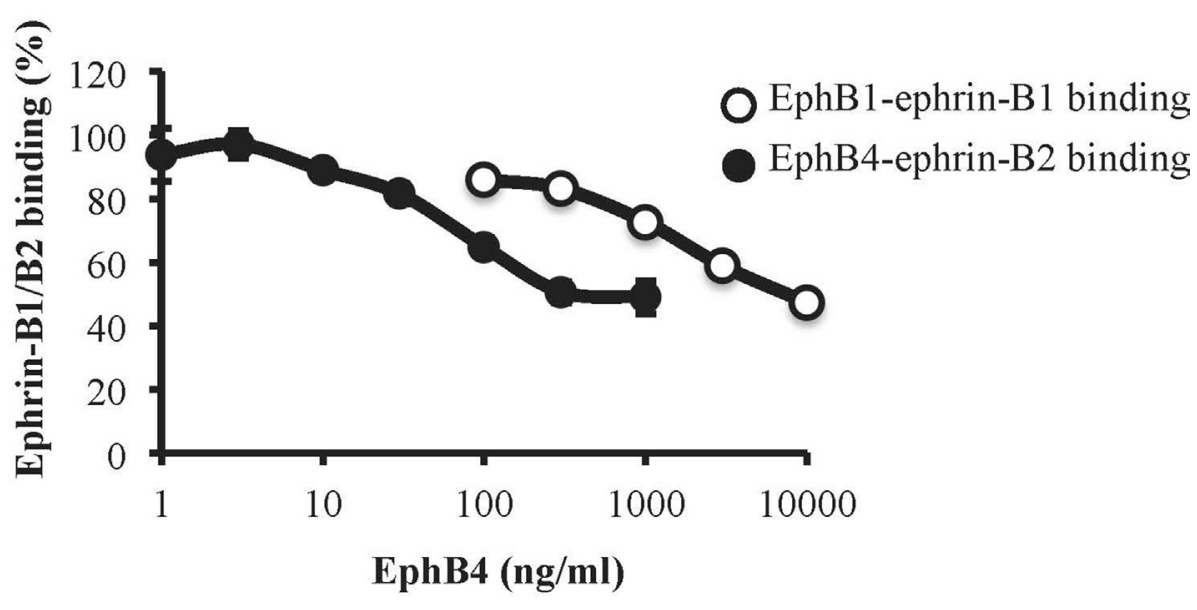

FIGURE 8 | Binding affinity of monomeric EphB4 to ephrin-B1 and ephrin-B2. EphB4 concentration-dependently displaced the binding of biotinylated ephrin-B1-Fc from immobilized EphB1-Fc (white circles) or the binding of biotinylated ephrin-B2-Fc from immobilized EphB4-Fc (black circles) $(n=3$ independent experiments).

through monomeric EphB4 and, on the other hand, by blocking forward signaling and activating the reverse one through EphB1-Fc. Accordingly, we could speculate that endogenous EphB/ephrin-B forward signaling plays a significant role in TNBSinduced inflammation and that its antagonism could represent a novel, promising approach to control the hapten-induced flogosis.

Given the increased levels of ephrin-B2 mRNA in the gut mucosal lesions of CD patients (Hafner et al., 2005), we then asked whether similar changes in the expression of ephrin-B2 ligand and of its preferential binding protein, the EphB4 receptor, occurred in TNBS-induced colitis: as a result, comparable levels of EphB4 mRNA and protein were detected in the colon of normal and colitic mice. As regard ephrin-B2 gene transcripts, the analysis revealed the presence of two bands corresponding to splice variants of ephrin-B2 gene. The existence of an alternate splice isoform of ephrin-B2, in which a conserved region of 31 amino acid residues was truncated, was demonstrated by Bergemann more than 20 years ago in mouse embryos nervous system (Bergemann et al., 1995); however, to the best of our knowledge, this is the first proof of its presence in mouse inflamed intestinal tissue. It is likely that pro-inflammatory cues may promote the altered expression of this shorter splice variant, as it has been demonstrated for other genes in IBD (Manousou et al., 2008; Matos et al., 2013); to this end, future studies will be 
pivotal to determine whether similar findings can be evidenced also in the colonic mucosa of other murine models of colitis and of IBD patients and to unravel its specific function. Interestingly, treatment with EphB4 was not able to prevent the generation of the alternative variant, despite its efficacy in counteracting the inflammatory responses in TNBS-induced colitis: this suggests that the anti-inflammatory action modulates down-stream factors apparently not involved in the transcriptional regulation of ephrin-B2 gene. As regard the mature protein, only a single band, presumably corresponding to ephrin-B2 longer product, could be detected through western blotting: technical issues, related to the low sensitivity of our experimental procedures, might explain the difficulty in revealing the protein encoded by the shorter mRNA sequence.

To get a deeper insight into the mechanism of the protective action afforded by EphB/ephrin-B antagonism specifically in TNBSinduced colitis, and given the pivotal role played by $\mathrm{T}$ lymphocytes in this model, we focused on adaptive immune cells involvement. Indeed, although the injury to colonic epithelium produced by DSS exposure is the first step leading to recruitment of innate immune cells, TNBS-induced colitis, triggered by haptenization of colonic tissue proteins, is considered primarily based on the activation of CD4 ${ }^{+}$Th1-mediated responses (Kiesler et al., 2015). Accordingly, in our TNBS model, a marked reduction of CD4 ${ }^{+}$ and $\mathrm{CD}^{+}$T lymphocytes was evident both in the spleen and MLN of colitic mice, suggesting the migration of $\mathrm{T}$ lymphocytes from secondary lymphoid organs to the site of inflammation, whereas no significant changes could be detected after DSS assumption. The ability of EphB4 to prevent the outflow of T cells from the spleen promoted by TNBS could presumably lead to a lower recruitment of adaptive immune cells, besides neutrophils, into the lamina propria, confirming our hypothesis of a protection involving T-cell modulation. Future investigations will help to unravel the matter.

Finally, we investigated the effects of EphB4 on the production of TNFa by isolated splenic mononuclear cells exogenously stimulated. It is well known that mitogen PMA and ionophore ionomycin stimulate cytokine gene expression in Tlymphocytes through $\mathrm{Ca}^{2+}$ dependent pathways, bypassing the TCR complex (Truneh et al., 1985; Savignac et al., 2007) and, as confirmed also by our results, in a manner sensitive to cyclosporine A, immunosuppressant drug able to block $\mathrm{Ca}^{2+}$-dependent responses (Almawi et al., 1999). Intriguingly, EphB4 was able to potentiate the production of TNFa from activated splenic mononuclear cells at a concentration interacting with ephrin-B2 but not with ephrin-B1. Despite the still underinvestigated contribution of Eph/ephrin system to the physiological regulation of immune responses, the ability of monomeric EphB4 to modulate mononuclear cells activation may reflect the role played by EphB4/ephrin-B2 couple in the regulation of lymphocytes activity: in particular, both stimulation and inhibition of $\mathrm{T}$ lymphocytes proliferation and pro-inflammatory cytokines release have been described for ephrin-B2/EphB forward signaling following anti-CD3 stimulation (Yu et al., 2003; Kawano et al., 2012). These observations led us to speculate that, in our experimental conditions, the increase in in vitro TNFa levels promoted by EphB4 is a possible consequence of the blockade of EphB forward signaling in splenic mononuclear cells and a result only apparently conflicting with its protective action in TNBS-induced colitis. Indeed, inside the multiform scenario of the biological actions of TNFa, both pathological and homeostatic

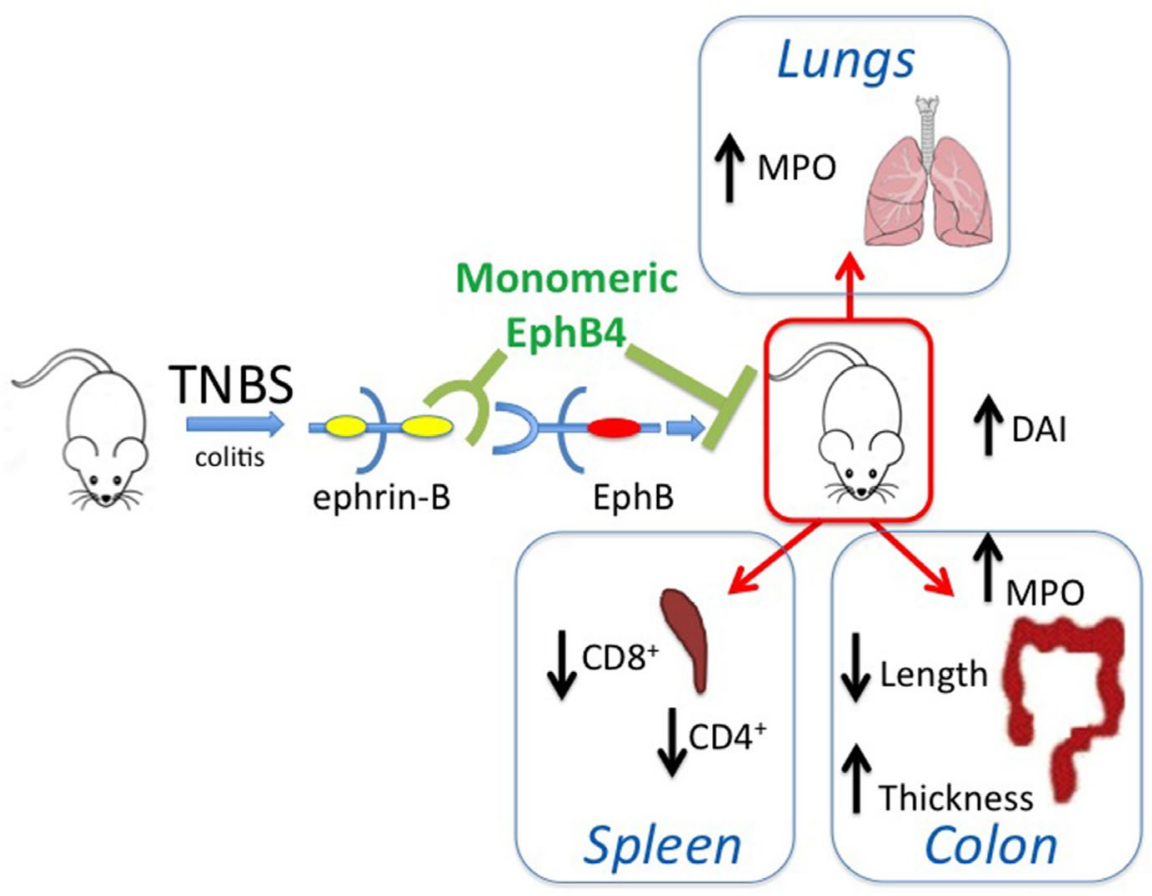

FIGURE 9 | Graphical summary. The scheme describes the main findings of the manuscript and represents the ability of monomeric protein EphB4 to counteract the TNBS-induced inflammatory responses by interfering with EphB-ephrin-B interaction. 
responses can be elicited by this cytokine in the gastrointestinal tract. If, on one side, anti-TNFa agents represent the mainstay in IBD therapy, also paradoxical GI adverse events for drugs neutralizing TNFa as well as the improvement of mucosal healing by TNFa during colitis have been reported over the past years (Bradford et al., 2017), reinforcing the notion of the Janus-faced role of this cytokine in intestinal inflammation (Dubé et al., 2015). Accordingly, the promotion of lymphocytes activation and of TNFa production by EphB4/ephrin-B2 blockade may contribute to balance the immune surveillance, controlling the flogistic cascade elicited by TNBS.

On the whole, the collected results, schematically represented in Figure 9, point to a potential role of the EphB/ephrin-B system as pharmacological target in intestinal inflammatory disorders and suggest that the therapeutic efficacy achieved by its blockade seemingly works through the modulation of immune responses and independent of changes at the transcriptional and translational level of EphB4 and ephrin-B2 genes in intestinal tissues.

\section{AUTHOR'S NOTE}

Preliminary data were presented at Digestive Disease Week 2018, June 2-5 2018, Washington (DC) (USA).

\section{DATA AVAILABILITY STATEMENT}

All datasets generated for this study are included in the manuscript and the supplementary files.

\section{ETHICS STATEMENT}

Animal experiments were performed according to the guidelines for the use and care of laboratory animals, and they were

\section{REFERENCES}

Almawi, W. Y., Assi, J. W., Chudzik, D. M., and Lazarovits, A. I. (1999). Opposing effects of rapamycin and cyclosporine a on activation-induced Ca2+ release. Eur. J. Pharmacol. 381, 51-56. doi: 10.1016/S0014-2999(99)00558-0

Barquilla, A., and Pasquale, E. B. (2015). Eph receptors and ephrins: therapeutic opportunities. Annu. Rev. Pharmacol. Toxicol. 55, 465-487. doi: 10.1146/ annurev-pharmtox-011112-140226

Bergemann, A. D., Cheng, H. J., Brambilla, R., Klein, R., and Flanagan, J. G. (1995). ELF-2, a new member of the Eph ligand family, is segmentally expressed in mouse embryos in the region of the hindbrain and newly forming somites. Mol. Cell Biol. 15, 4921-4929. doi: 10.1128/MCB.15.9.4921

Bischoff, S. C., Mailer, R., Pabst, O., Weier, G., Sedlik, W., Li, Z., et al. (2009). Role of serotonin in intestinal inflammation: knock out of serotonin reuptake transporter exacerbates 2,4,6-trinitrobenzene sulfonic acid colitis in mice. Am. J. Physiol. Gastrointest. Liver Physiol. 296, G685-G695. doi: 10.1152/ajpgi.90685.2008

Bradford, E. M., Ryu, S. H., Singh, A. P., Lee, G., Goretsky, T., Sinkh, P., et al. (2017). Epithelial TNF receptor signalling promotes mucosal repair in inflammatory bowel disease. J. Immunol. 199, 1886-1897. doi: 10.4049/jimmunol.1601066

Bramhall, M., Florez-Vargas, O., Stevens, R., Brass, A., and Cruickshank, S. (2015). Quality of methods reporting in animal models of colitis. Inflamm. Bowel. Dis. 21, 1248-1259. doi: 10.1097/MIB.0000000000000369 authorized by the local Animal Care Committee "Organismo Preposto al Benessere degli Animali" and by Italian Ministry of Health "Ministero della Salute" (DL 26/2014).

\section{AUTHOR CONTRIBUTIONS}

AG, IZ, SP, GC, LF performed the experiments and analyzed the data; AMC carried out the histological analysis; SBr and FM supervised RT-PCR and gene sequencing assays; AF supervised in vitro assays; $\mathrm{RC}$ and $\mathrm{AL}$ supervised the binding assays; $\mathrm{SBe}, \mathrm{EB}$ and MT designed the research and supervised the experiments; AG, IZ, and SBe wrote the manuscript; all the authors critically revised the manuscript, finally approved it and agreed to be accountable for all aspects of the work.

\section{FUNDING}

This work was supported by FFABR_2017_MIUR grants to SB, $\mathrm{EB}$, and MT.

\section{ACKNOWLEDGMENTS}

The authors wish to thank Dr. Giuseppe Domenichini for his skillful technical assistance and Dr. Daniele Cretella and Dr. Silvia La Monica for providing Nanodrop ND-1000 and for helping with RT-PCR analysis.

\section{SUPPLEMENTARY MATERIAL}

The Supplementary Material for this article can be found online at: https://www.frontiersin.org/articles/10.3389/fphar.2019.00691/ full\#supplementary-material

Cooper, H. S., Murthy, S. N., Shah, R. S., and Sedergran, D. J. (1993). Clinicopathological study of dextran sulfate sodium experimental murine colitis. Lab. Invest. 69, 238-249.

Dubé, P. E., Punit, S., and Brent Polk, D. (2015). Redeeming an old foe: protective as well pathophysiological roles for tumor necrosis factor in inflammatory bowel disease. Am. J. Physiol. Gastrointest. Liver. Physiol. 308, G161-G170. doi: 10.1152/ajpgi.00142.2014

Funk, S. D., and Orr, A. W. (2013). Ephs and ephrins resurface in inflammation, immunity and atherosclerosis. Pharmacol. Res. 67, 42-52. doi: 10.1016/j. phrs.2012.10.008

Giorgio, C., Incerti, M., Pala, D., Russo, S., Chiodelli, P., Rusnati, M., et al. (2019). Inhibition of Eph/ephrin interaction with the small molecule UniPR500 improves glucose tolerance in healthy and insulin-resistant mice. Pharmacol. Res. 141, 319-330. doi: 10.1016/j.phrs.2019.01.011

Grandi, A., Zini, I., Flammini, L., Cantoni, A. M., Vivo, V., Ballabeni, V., et al. (2017). a7 Nicotinic agonist AR-R17779 protects mice against 2,4,6-trinitrobenzene sulfonic acid-induced colitis in a spleen-dependent way. Front. Pharmacol. 8, 809. doi: 10.3389/fphar.2017.00809

Hafner, C., Meyer, S., Langmann, T., Schmitz, G., Bataille, F., Hagen, I., et al. (2005). Ephrin-B2 is differentially expressed in the intestinal epithelium in Crohn's disease and contributes to accelerated epithelial wound healing in vitro. World J. Gastroenterol. 11, 4024-4031. doi: 10.3748/wjg.v11.i26.4024 
Jin, W., Luo, H., and Wu, J. (2014). Effect of reduced EPHB4 expression in thymic epithelial cells on thymocyte development and peripheral $\mathrm{T}$ cell function. Mol. Immunol. 58, 1-9. doi: 10.1016/j.molimm.2013.10.008

Kania, A., and Klein, R. (2016). Mechanisms of ephrin-Eph signalling in development, physiology and disease. Nat. Rev. Mol. Cell Biol. 17, 240-256. doi: $10.1038 / \mathrm{nrm} .2015 .16$

Kaser, A., Zeissig, S., and Blumberg, R. S. (2010). Inflammatory bowel disease. Annu. Rev. Immunol. 28, 573-621. doi: 10.1146/annurev-immunol-030409-101225

Kawano, H., Katayama, Y., Minagawa, K., Shimoyama, M., Henkemeyer, M., and Matsui, T. (2012). A novel feedback mechanism by Ephrin-B1/B2 in T-cell activation involves a concentration-dependent switch from co-stimulation to inhibition. Eur. J. Immunol. 42, 1562-1572. doi: 10.1002/eji.201142175

Kertesz, N., Krasnoperov, V., Reddy, R., Leshanski, L., Kumar, S. R., Zozulya, S., et al. (2006). The soluble extracellular domain of EphB4 (sEphB4) antagonizes EphB4-EphrinB2 interaction, modulates angiogenesis, and inhibits tumor growth. Blood 107, 2330-2338. doi: 10.1182/blood-2005-04-1655

Kiesler, P., Fuss, I. J., and Strober, W. (2015). Experimental models of inflammatory bowel disease. Cell. Mol. Gastroenterol. Hepatol. 1, 154-170. doi: 10.1016/j. jcmgh.2015.01.006

Klein, A. B., Witonsky, S. G., Ansar Ahmed, S., Holladay, S. D., and Gogal, R. M. (2006). Impact of different cell isolation techniques on lymphocyte viability and function. J. Immunoassay Immunochem. 27, 61-76. doi: $10.1080 / 15321810500403755$

Kruisbeek, A. M. (2001). Isolation of mouse mononuclear cells. Curr. Protoc. Immunol. 39, 3.1.1-3.1.5. doi: 10.1002/0471142735.im0301s39

Li, Y-h, Zhang, M., Xiao, H-t, Fu, H-b, Ho, A., C-y, Lin, et al. (2015). Addition of berberine to 5 -aminosalycilic acid for treatment of dextran sulphate sodiuminduced chronic colitis in C57BL/6 mice. PLoS One 10 (12), e0144101. doi: 10.1371/journal.pone.0144101

Lodola, A., Giorgio, C., Incerti, M., Zanotti, I., and Tognolini, M. (2017). Targeting Eph/ephrin system in cancer therapy. Eur. J. Med. Chem. 142, 152-162. doi: 10.1016/j.ejmech.2017.07.029

Manousou, P., Kolios, G., Drygiannakis, I., Pyrovolaki, K., Bourikas, L., and Papadaki, H. A. (2008). Expression of a splice variant of CXCR3 in Crohn's disease patients: indication for a lymphocyte-epithelial cell interaction. J. Gastroenterol. Hepatol. 23, 1823-1833. doi: 10.1111/j.1440-1746.2008.05486.x

Matos, P., Kotelevets, L., Goncalves, V., Henriques, A., Zerbib, P., Moyer, M. P., et al. (2013). Ibuprofen inhibits colitis-induced overexpression of tumorrelated Rac1b. Neoplasia 15, 102-111. doi: 10.1593/neo.121890

Moore-Olufemi, S. D., Kozar, R. A., Moore, F. A., Sato, N., Hassoun, H. T., Cox, C. S., Jr., et al. (2005). Ischemic preconditioning protects against gut dysfunction and mucosal injury after ischemia/reperfusion injury. Shock 23, 258-263. doi: 10.1097/00024382-200406002-00179

Ogawa, K., Wada, H., Okada, N., Harada, I., Nakajima, T., Pasquale, E. B., et al. (2006). EphB2 and ephrin-B1 expressed in the adult kidney regulate the cytoarchitecture of medullary tubule cells through Rho family GTPases. J. Cell Sci. 119, 559-570. doi: $10.1242 /$ jcs.02777

Pasquale, E. B. (2005). Eph receptor signaling casts a wide net on cell behaviour. Nat. Rev. Mol. Cell Biol. 6, 462-475. doi: 10.1038/nrm1662

Perez White, B. E., and Getsios, S. (2014). Eph receptor and ephrin function in breast, gut, and skin epithelia. Cell Adh. Migr. 8, 327-338. doi: 10.4161/ 19336918.2014.970012

Pfaff, D., Heroult, M., Riedel, M., Reiss, Y., Kirmse, R., Ludwig, T., et al. (2008). Involvement of endothelial ephrin-B2 in adhesion and transmigration of EphBreceptor-expressing monocytes. J. Cell Sci. 121, 3842-3850. doi: 10.1242/jcs.030627

Rapalli, A., Bertoni, S., Arcaro, V., Saccani, F., Grandi, A., Vivo, V., et al. (2016). Dual role of endogenous serotonin in 2,4,6-trinitrobenzene sulfonic acidinduced colitis. Front. Pharmacol. 7, 68. doi: 10.3389/fphar.2016.00068

Satoh, Y., Ishiguro, Y., Sakuraba, H., Kawaguchi, S., Hiraga, H., Fukuda, S., et al. (2009). Cyclosporine regulates intestinal epithelial apoptosis via TGF-b-related signalling. Am. J. Physiol. Gastrointest. Liver. Physiol. 297, G514-G519. doi: 10.1152/ajpgi.90608.2008

Savignac, M., Mellstrom, B., and Naranjo, J. R. (2007). Calcium-dependent transcription of cytokine genes in T lymphocytes. Pflugers Arch. Eur. J. Physiol. 454, 523-533. doi: 10.1007/s00424-007-0238-y

te Velde, A. A., Verstege, M. I., and Hommes, D. W. (2006). Critical appraisal of the current practice in murine TNBS-induced colitis. Inflamm. Bowel. Dis. 12, 995-999. doi: 10.1097/01.mib.0000227817.54969.5e

Truneh, A., Albert, F., Golstein, P., and Schmitt-Verhulst, A. M. (1985). Early steps of lymphocyte activation bypassed by synergy between calcium ionophores and phorbol ester. Nature 313, 318. doi: 10.1038/313318a0

Vivo, V., Zini, I., Cantoni, A. M., Grandi, A., Tognolini, M., Castelli, R., et al. (2017). Protection by the Eph-ephrin system against mesenteric ischemiareperfusion injury. Shock 48, 681-689. doi: 10.1097/SHK.0000000000000890

Waldner, M. J., and Neurath, M. F. (2009). Chemically induced mouse models of colitis. Curr. Protoc. Pharmacol. 5, 55.1-5-55.15. doi: 10.1002/0471141755.ph0555s46

Yu, G., Luo, H., Wu, Y., and Wu, L. (2003). Ephrin B2 induces T cell costimulation. J. Immunol. 171, 106-114. doi: 10.4049/jimmunol.171.1.106

Conflict of Interest Statement: The authors declare that the research was conducted in the absence of any commercial or financial relationships that could be construed as a potential conflict of interest.

Copyright () 2019 Grandi, Zini, Palese, Giorgio, Tognolini, Marchesani, Bruno, Flammini, Cantoni, Castelli, Lodola, Fusari, Barocelli and Bertoni. This is an openaccess article distributed under the terms of the Creative Commons Attribution License (CC BY). The use, distribution or reproduction in other forums is permitted, provided the original author(s) and the copyright owner(s) are credited and that the original publication in this journal is cited, in accordance with accepted academic practice. No use, distribution or reproduction is permitted which does not comply with these terms. 